\title{
Diatom assemblages (Bacillariophyta) in six tropical reservoirs from southeast Brazil: species composition and spatial and temporal variation patterns
}

Assembléias de diatomáceas (Bacillariophyta) em seis reservatórios tropicais no sudeste do Brasil: composição de espécies e padróes de variação temporal e espacial

Gisele Carolina Marquardt ${ }^{1 *}$, Carlos Eduardo de Mattos Bicudo ${ }^{1}$, Thelma Alvim Veiga Ludwig²,

$$
\text { Luc Ector }{ }^{3} \text { and Carlos E. Wetzel }{ }^{3}
$$

${ }^{1}$ Núcleo de Pesquisas em Ecologia, Instituto de Botânica, Av. Miguel Estéfano, 3687, CEP 04301-012, São Paulo, SP, Brasil

${ }^{2}$ Departamento de Botânica, Universidade Federal do Paraná - UFPR, Avenida Coronel Francisco H. dos Santos, 100, Jardim das Américas, CP 19031, CEP 81531-980, Curitiba, PR, Brasil

${ }^{3}$ Environmental Research and Innovation Department, Luxembourg Institute of Science and Technology, 41 rue du Brill, L-4422 Belvaux, Grand-duchy of Luxembourg

*e-mail: giselecmarquardt@gmail.com

Cite as: Marquardt, G.C. et al. Diatom assemblages (Bacillariophyta) in six tropical reservoirs from southeast Brazil: species composition and spatial and temporal variation patterns. Acta Limnologica Brasiliensia, 2018, vol. 30, e201.

Abstract: Aim: Relationships between species composition and variation patterns in diatom assemblages over six tropical reservoirs located in Southeast Brazil were explored. Methods: Surface-sediment and phytoplankton diatom assemblages were determined and Canonical Correspondence Analysis was used to verify the set of environmental variables that best explain the species composition variation among sites. Results: A total of 28 diatom taxa representing 20 genera were identified using light and scanning electron microscopy. Information on their ecological preferences was also provided. Humidophila biscutella is reported for the first time in Brazil whereas Sellaphora sassiana and Humidophila brekkaensis are reported for the first time in São Paulo State. Three groups of potential water quality indicators were delineated: the first suggests oligotrophic conditions, the second is related to cold waters with low luminosity in a mixing regime, and the third is a small group of tolerant species occurring in water with high conductivity, $\mathrm{pH}$ and total phosphorus conditions. Conclusion: present study provided the first insight into the general diatom communities over six tropical reservoirs in Southeast Brazil and provided information on their ecology and distribution aiming bioassessment. The potential of water quality indicator diatom groups here outlined are in line with those reported in the literature and reinforce the importance of PEJU for the maintenance of ecological quality of reservoirs and reference conditions for the Metropolitan Region of São Paulo water sources.

Keywords: bioassessment; Canonical Correspondence Analysis; trophic state; São Paulo.

Resumo: Objetivo: As relaçóes entre composição de espécies e padrôes de variação nas comunidades de diatomáceas foram exploradas em seis reservatórios tropicais localizados no sudeste do Brasil. Métodos: Diatomáceas fitoplanctônicas e de sedimentos superficiais foram determinadas e a Análise de Correspondência Canônica foi utilizada para identificar o conjunto de variáveis 
ambientais que melhor explica a variação da composição das espécies entre as unidades amostrais. Resultados: $\mathrm{O}$ total de 28 táxons de diatomáceas representando 20 gêneros foi identificado utilizando microscopia de luz e eletrônica de varredura; e foram fornecidas informaçóes sobre suas preferências ecológicas. Humidophila biscutella é reportada pela primeira vez no Brasil e Sellaphora sassiana e Humidophila brekkaensis foram registradas pela primeira vez no Estado de São Paulo. Foram delineados três grupos de potenciais indicadores da qualidade da água que sugerem condiçóes oligotróficas, águas com baixa luminosidade e em regime de mistura além de um pequeno grupo de espécies tolerantes ocorrentes em águas com elevada condutividade, $\mathrm{pH}$ e total fósforo total. Conclusáo: $\mathrm{O}$ presente estudo forneceu uma primeira visão sobre as comunidades de diatomáceas em geral de seis reservatórios tropicais do sudeste do Brasil e providenciou informaçáo sobre sua ecologia e distribuição, contribuindo para o conhecimento das diatomáceas tropicais com vista à bioavaliação. Os grupos potenciais de diatomáceas indicadores de qualidade da água delineados seguem o reportado na literatura e reforçam a importância da PEJU para a manutenção da qualidade ecológica dos reservatórios e condiçóes de referência para as fontes de água da Região Metropolitana de São Paulo.

Palavras-chave: bioindicação; Análise de Correspondência Canônica; estado trófico; São Paulo.

\section{Introduction}

Diatoms are routinely used in environmental status assessment because of their importance in food webs and biochemical linkages, and due to their sensitivity to physical, chemical and biological disturbances (Stenger-Kovács et al., 2007; Bolla et al., 2010; Chételat et al., 2010; Kireta et al., 2012; B-Béres et al., 2014). Diatoms respond predictably to many water chemistry variables, besides having a relatively well known ecology (Soininen et al., 2007). Factors such as choice of sampling site and methods for preparing and processing samples and identifying taxa can be crucial to the assessment results (Besse-Lototskaya et al., 2006) as their use as environmental indicators requires high taxonomic precision (Birks, 1994).

The composition of diatom communities reflects an entire complex of ecological parameters at a particular site (van Dam et al., 1994; Resende et al., 2005). In this sense, floristic surveys support not only applied research projects, such as water quality monitoring, but also a wide range of basic research issues from taxonomic revisions and monographs, phylogenetic reconstruction, biogeographical studies, as well as ecological, physiological, restoration, and conservation biology research programs (Kociolek, 2006).

Although floristic diatom surveys have been carried out in Brazil (e.g. Ferrari \& Ludwig, 2007; Cavalcante et al., 2014; Silva et al., 2016), they are greatly concentrated in the South and Southeast regions of the country (e.g. Moura \& Bittencourt-Oliveira, 2004; Bertolli et al., 2010; Faria et al., 2010; Souza-Mosimann et al., 2011; Bes et al., 2012; Bartozek et al., 2013; Nardelli et al., 2014; Marra et al., 2016). Specifically for São Paulo State, studies are mainly a result of the
Biota-FAPESP, an important project that aims at identifying the local algal flora (e.g. Carneiro \& Bicudo, 2007; Rocha \& Bicudo, 2008; Marquardt \& Bicudo, 2014; Wengrat et al., 2015).

In addition, ecological (e.g. Wengrat $\&$ Bicudo, 2011; Bicudo et al., 2016) and paleolimnological (e.g. Costa-Böddeker et al., 2012; Fontana et al., 2014; Faustino et al., 2016) surveys are also available under the AcquaSed Project (Base line diagnosis and reconstruction of anthropogenic impacts in the Guarapiranga Reservoir, focusing on the water supply sustainability and water quality management in reservoirs of the Upper Tietê and surrounding basins), thus contributing to the knowledge of tropical diatom with emphasis on bioassessment. This project has also led to the development of a range of taxonomic surveys (e.g. Almeida \& Bicudo, 2014; Almeida et al., 2015, 2016; Marquardt et al., 2016; Wengrat et al., 2016). However, there still are considerable gaps in sampling sites in São Paulo in which the size and diversity of habitats can be considered one of the reasons for the large number of unexplored areas.

The aim of this study was to provide the first insight into the general diatom assemblages over six tropical reservoirs in Southeast Brazil by investigating their species composition as well as their distribution along a spatial and temporal gradient to examine the variation in diatom communities among reservoirs, habitats and seasons.

\section{Material and Methods}

\subsection{Study area}

Reservoirs studied are located at two different basins in southeastern São Paulo State: Ribeira do Iguape/Litoral Sul and Alto Paranapanema. Three reservoirs (Cachoeira do França, Cachoeira 
da Fumaça and Serraria) are connected with the same water course (Juquiá River), whereas the other three (Jurupará, Salto do Iporanga and Paineiras) are located in three different rivers (Rio dos Peixes, Assungui and Turvo rivers, respectively) (Figure 1). Mean elevation range varied from 17 to $996 \mathrm{~m}$ a.s.l. All study sites were located in well preserved areas, most of them located in areas of the PEJU State Park (Parque Estadual do Jurupará). Presently, reservoirs were classified mostly oligotrophic to mesotrophic (Lamparelli, 2004) with no obvious signs of human impact. The area is a protected representative of Atlantic forest in the São Paulo Atlantic Plateau, in which 77 species of fauna and flora currently endangered and 182 endemic species besides more than 300 new species records were recorded (São Paulo, 2010). However, the diatom flora is virtually unknown in this area.

\subsection{Sampling}

Samplings covered two distinct habitats (plankton and surface sediments) from 20 sampling sites distributed along the reservoirs during austral summer and winter of 2014. Plankton samples were obtained with van Dorn water sampler along a vertical profile of the reservoirs. Surface sediments were taken with a gravity core (UWITEC) and the top $2 \mathrm{~cm}$ sections were saved for analyses.

Environmental parameters (temperature $\left({ }^{\circ} \mathrm{C}\right), \mathrm{pH}$ and conductivity) were measured in the field using a multiparameter probe (Horiba U-53) and the analytical procedure for dissolved oxygen, ammonium, nitrate, soluble reactive silica, total nitrogen and total phosphorus, free carbon dioxide and bicarbonate ions followed Standard Methods (APHA, 2005). Chlorophyll-a, corrected for phaeophytin was measured using 90\% ethanol (Sartory \& Grobbelaar, 1984) (Table 1). The Trophic State Index (TSI) was calculated according to Lamparelli (2004).

\subsection{Slides preparation and counting}

Diatom samples were processed by hot digestion using hydrogen peroxide $\left(\mathrm{H}_{2} \mathrm{O}_{2}\right)$ and $\mathrm{HCl}(37 \%)$. Peroxide and acid were removed through a series of dilutions. Subsequently, the samples were dried onto cover glass and mounted in Naphrax (R.I. $=1.74$ ) according to Battarbee (1986), and examined with a Zeiss Axio Imager A2 light microscope (LM) equipped with DIC and a digital camera model AxioCamMR5. SEM images were taken in three different research centers: LIST, Luxembourg Institute of Science and Technology, UFPR,

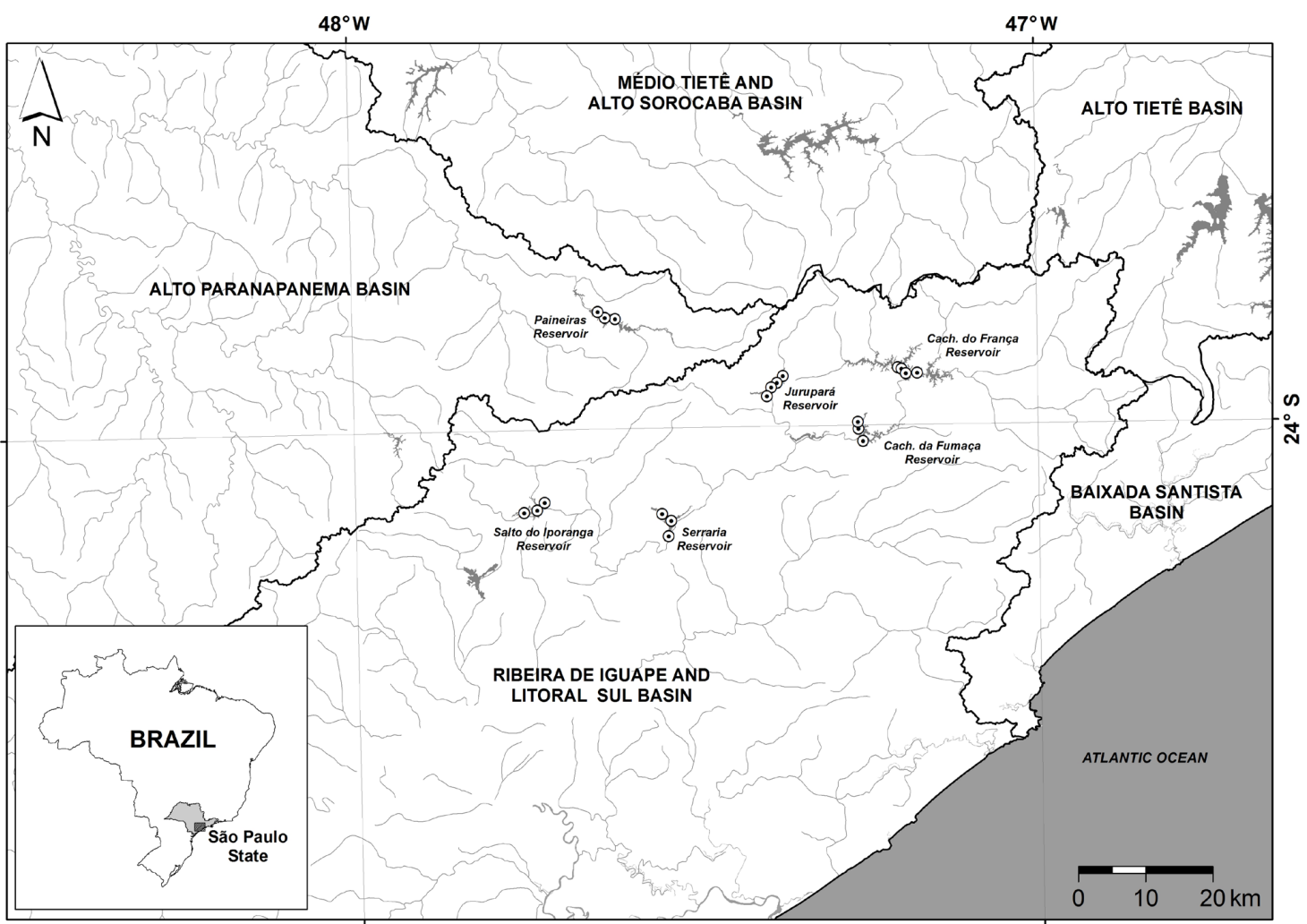

Figure 1. Study area and sampling sites. 
Table 1. Means and standard deviation of abiotic variables in the six studied reservoirs. The other variables were eliminated because of collinearity. Abbreviations: Sec (Secchi depth), pH, Cond (Conductivity), TN (Total nitrogen), TP (Total phosphorus), SRS (Soluble reactive silica), Chlo (Chlorophyll-a), TSI (Trophic State Index). FR (Cachoeira do França), FU (Cachoeira da Fumaça), SE (Serraria), JP (Jurupará), SI (Salto do Iporanga), PI (Paineiras). Numbers refer to sample units.

\begin{tabular}{lllllcccc}
\hline & Sec $(\mathbf{m})$ & \multicolumn{1}{c}{$\mathbf{p H}$} & $\begin{array}{c}\text { Cond } \\
\left(\boldsymbol{\mu} \mathbf{~} \mathbf{~ m}^{-1}\right)\end{array}$ & $\begin{array}{c}\text { TN } \\
\left(\boldsymbol{\mu g} \cdot \mathbf{L}^{-1}\right)\end{array}$ & $\begin{array}{c}\text { TP } \\
\left(\boldsymbol{\mu g} \cdot \mathbf{L}^{-1}\right)\end{array}$ & $\begin{array}{c}\text { SRS } \\
\left(\mathbf{m g} \cdot \mathbf{L}^{-1}\right)\end{array}$ & $\begin{array}{c}\text { Chlo } \\
\left(\boldsymbol{\mu g} \cdot \mathbf{L}^{-1}\right)\end{array}$ & $\begin{array}{c}\text { TSI } \\
(\text { Anual Mean })\end{array}$ \\
\hline FR1 & $1.7 \pm 8.5$ & $7.3 \pm 0.9$ & $24.8 \pm 0.7$ & $151.8 \pm 162.9$ & $5.5 \pm 2.2$ & $2.4 \pm 1.3$ & $5.4 \pm 4.8$ & Oligotrophic \\
FR2 & $1.9 \pm 0.2$ & $7.3 \pm 1.3$ & $24.8 \pm 0.75$ & $191.1 \pm 45$ & $10.0 \pm 7.5$ & $2.39 \pm 1.2$ & $4.12 \pm 2$ & Oligotrophic \\
FR3 & $1.7 \pm 0.005$ & $7.9 \pm 0.6$ & $23.5 \pm 2.1$ & $231.2 \pm 21.2$ & $6.6 \pm 3.7$ & $2.3 \pm 1.4$ & $20.2 \pm 26.5$ & Oligotrophic \\
FR4 & $1.7 \pm 0.1$ & $8.6 \pm 0.6$ & $24.5 \pm 3.5$ & $280.0 \pm 153.7$ & $6.8 \pm 2.5$ & $2.2 \pm 1.3$ & $22.8 \pm 29.7$ & Oligotrophic \\
FU1 & $2.6 \pm 1.7$ & $6.5 \pm 0$ & $26.5 \pm 0.7$ & $228.6 \pm 13.7$ & $5.1 \pm 1.6$ & $2.5 \pm 1$ & $1.7 \pm 0.4$ & Ultraoligotrophic \\
FU2 & $2.8 \pm 1.5$ & $6.8 \pm 0.7$ & $26.0 \pm 2.8$ & $176.5 \pm 66.1$ & $8.4 \pm 2.1$ & $2.4 \pm 1$ & $3.4 \pm 1.1$ & Oligotrophic \\
FU3 & $2.1 \pm 0.3$ & $6.6 \pm 0.4$ & $26.0 \pm 1.4$ & $180.1 \pm 71.7$ & $5.8 \pm 2.7$ & $2.3 \pm 1$ & $3.3 \pm 2.3$ & Oligotrophic \\
SE1 & $4.0 \pm 1.8$ & $7.4 \pm 1.1$ & $21.0 \pm 9.9$ & $180.3 \pm 64.1$ & $8.1 \pm 2.9$ & $4.4 \pm 1.2$ & $1.8 \pm 0.7$ & Oligotrophic \\
SE2 & $3.7 \pm 1.4$ & $7.3 \pm 0.6$ & $25.0 \pm 2.8$ & $174.7 \pm 80$ & $8.0 \pm 1.5$ & $3.9 \pm 1.5$ & $4.6 \pm 2.2$ & Oligotrophic \\
SE3 & $4.2 \pm 1.4$ & $6.6 \pm 0.2$ & $28.5 \pm 2.1$ & $216.0 \pm 147.7$ & $8.5 \pm 3.7$ & $3.6 \pm 1.5$ & $7.6 \pm 0.7$ & Oligotrophic \\
JP1 & $1.5 \pm 0.8$ & $6.4 \pm 1.3$ & $24.0 \pm 2.8$ & $464.3 \pm 89.4$ & $19.5 \pm 4.2$ & $3.9 \pm 0.3$ & $16.8 \pm 1.8$ & Mesotrophic \\
JP2 & $1.9 \pm 0.4$ & $6.6 \pm 0.1$ & $23.5 \pm 3.5$ & $351.4 \pm 201.4$ & $16.6 \pm 0.3$ & $3.8 \pm 0.3$ & $10.1 \pm 0.7$ & Mesotrophic \\
JP3 & $2.2 \pm 0.2$ & $6.6 \pm 0.1$ & $24.0 \pm 2.8$ & $453.3 \pm 8.2$ & $13.5 \pm 0.7$ & $3.7 \pm 0.3$ & $7.1 \pm 1.2$ & Mesotrophic \\
JP4 & $2.1 \pm 0.4$ & $6.8 \pm 0.2$ & $23.5 \pm 3.5$ & $434.1 \pm 103.8$ & $13.3 \pm 1.9$ & $3.94 \pm 0.32$ & $6.6 \pm 3.7$ & Oligotrophic \\
SI1 & $1.5 \pm 0.2$ & $8.0 \pm 2.1$ & $50.0 \pm 9.9$ & $415.9 \pm 143.2$ & $32.1 \pm 3.7$ & $5.1 \pm 1.6$ & $36.7 \pm 37.6$ & Mesotrophic \\
S12 & $1.9 \pm 0.4$ & $7.8 \pm 2$ & $43.5 \pm 7.8$ & $315.9 \pm 28.4$ & $23.1 \pm 1.5$ & $4.9 \pm 0.7$ & $17.4 \pm 15.3$ & Mesotrophic \\
S13 & $1.7 \pm 0.6$ & $7.9 \pm 2.1$ & $43.0 \pm 11.3$ & $304.4 \pm 22.4$ & $25.6 \pm 3.8$ & $4.1 \pm 1.5$ & $36.8 \pm 44$ & Mesotrophic \\
PI1 & $0.7 \pm 0.7$ & $6.7 \pm 0.4$ & $39.0 \pm 2.8$ & $310.8 \pm 119.3$ & $20.3 \pm 0.3$ & $4.6 \pm 0.4$ & $9.8 \pm 5.7$ & Mesotrophic \\
PI2 & $1.3 \pm 0.5$ & $6.9 \pm 0.6$ & $38.5 \pm 2.1$ & $258.4 \pm 258.4$ & $16.2 \pm 0.4$ & $4.6 \pm 0.8$ & $6.9 \pm 2.7$ & Mesotrophic \\
PI3 & $1.3 \pm 0.3$ & $7.1 \pm 0.5$ & $38.0 \pm 2.8$ & $289.4 \pm 218.8$ & $16.3 \pm 2$ & $4.5 \pm 0.8$ & $4.8 \pm 3.1$ & Oligotrophic \\
\hline
\end{tabular}

Universidade Federal do Paraná and Instituto de Botânica. For scanning electron microscope (SEM) observations, cleaned samples were filtered with additional deionized water through a $3 \mu \mathrm{m}$ isopore polycarbonate membrane filter (Merck Millipore). Filter was mounted on aluminum stubs and coated with platinum using a Modular High Vacuum Coating System BAL-TEC MED 020 (BAL-TEC AG, Balzers, Liechtenstein). An ultrahigh-resolution analytical field emission (FE) scanning electron microscope Hitachi SU-70 (Hitachi High-Technologies Corporation, Japan) operated at $5 \mathrm{kV}$ and $10 \mathrm{~mm}$ working distance was used for the analyses. SEM images were taken using the lower (SE-L) and upper (SE-U) detector signal at the LIST. Also, a subsample of the oxidized material was placed on aluminum stubs and coated with gold at $1 \mathrm{kV}$ for $5 \mathrm{~min}$ in a Balzers Sputtering/SDC030 sputter coater, and SEM observations were made with a JEOL JSM $6360 \mathrm{LV}$, operated at $15 \mathrm{kV}$ at $8 \mathrm{~mm}$ distance at the UFPR as well as with a Phillips 20XL operated at $10 \mathrm{kV}$ at the Instituto de Botânica. Micrographs were digitally manipulated and plates containing light and scanning electron microscopy images were created using CorelDraw X7. Morphometric information is provided for all taxa [D: diameter $(\mu \mathrm{m})$; L: length $(\mu \mathrm{m})$; W: width $(\mu \mathrm{m})$; $\mathrm{SH}$ : semi cell height $(\mu \mathrm{m})$; $S$ : striae in $10 \mu \mathrm{m}$; A: areolae in $10 \mu \mathrm{m}]$.

Taxonomy and nomenclature followed classic works and new publications (e.g. Krammer, 2000; Metzeltin et al., 2005; Lange-Bertalot et al., 2011) and the on-line catalogue of valid names (California Academy of Sciences, 2011). Classification systems followed Medlin \& Kaczmarska (2004) for supra-ordinal taxa, and Round et al. (1990) for subordinal taxa, except for genera published subsequently to this work. To account for the species distribution in Brazil and the State of São Paulo, literature with illustrations or sufficient taxonomic description of the species were considered.

Diatom quantification was made at 1000× magnification using a Zeiss Axioskop 2 microscope. At least 400 valves were counted per slide (Battarbee, 1986) with a minimum sampling efficiency of 90\% (Pappas \& Stoermer, 1996). Species abundances were calculated and expressed as a percentage of the total diatom count in each sample.

All slides used for diatom identification and enumeration were deposited at the "Herbário Científico do Estado Maria Eneyda P. Kauffmann 
Fidalgo" (SP), São Paulo State Department of Environment, Brazil.

\subsection{Statistical analyses}

We used the unimodal-based method based on Detrended Correspondence Analysis (DCA) by checking the length of the first DCA axis (length of gradient 2.5) (Birks, 2010). Final ordination was based on a canonical correspondence analysis (CCA) in order to extract major gradients among combinations of explanatory variables in a dataset. We used a stepwise function selection to obtain a subset of explanatory variables from the set of all variables available for the constrained ordination. We further performed a PERMANOVA two-way for two different groups: (i) reservoirs and (ii) habitats (surface sediments and phytoplankton for both seasons) in order to evaluate which factor structures the diatom community.

We downweighted our data of rare species by applying a $2 \%$ cut off on the relative abundance and eliminated all taxa occurring in less than two samples, because individual samples with rare species may distort the results of the analyses (Birks, 2010). Also, much of the observed species were rare and composed singletons making the species richness very high, consequently obstructing the taxonomic identification. The environmental variables were standardized and species abundances were Hellinger-transformed. Hellinger distance is the recommended measure for clustering or ordinating species abundance data (Legendre \& Gallagher, 2001). Diatom names were coded according to the OMNIDIA software (Lecointe et al., 1993).
Ordination techniques were performed in software R v. 3.0.2 (R Core Team, 2014) with the vegan package (Oksanen et al., 2016).

\section{Results}

\subsection{Taxonomy}

A total of 28 species of diatoms belonging to 20 genera was identified for the planktonic and surface sediments communities of the six sampled reservoirs. Only three species (Discostella stelligera (Cleve \& Grunow) Houk \& Klee, Aulacoseira tenella (Nygaard) Simonsen and Spicaticribra kingstonii J.R.Johansen, Kociolek \& R.L.Lowe were considered dominant ( $>50 \%$ in relative abundance) (Figures $2 \mathrm{~A}, \mathrm{~B}$ and $\mathrm{C}$ ) and three groups of potential water quality indicators were delineated (Figure 3). Identification was carried out to species level in 27 cases and to genus level in 2 cases. Morphometric data for the studied diatom species are offered in Table 2, and illustrated in Figures 4-132. Humidophila biscutella (Gerd Moser, Lange-Bertalot \& Metzeltin) R.L.Lowe et al. is reported for the first time in Brazil (Table 2, preceded by an asterisk**). Sellaphora sassiana (Metzeltin \& Lange-Bertalot) C.E. Wetzel and Humidophila brekkaensis (J.B.Petersen) R.L.Lowe et al. were reported for the first time in São Paulo State (Table 2, preceded by an asterisk*).

\subsection{Canonical correspondence analysis}

The CCA biplot with the selected variables are illustrated in Figure 3. PERMANOVA two-way analysis showed significant among-group differences both among reservoirs and habitats $(\mathrm{F}=5.36$; $\mathrm{P}>0.05)$ and habitats $(\mathrm{F}=4.98 ; \mathrm{P}>0.05)$. Habitat:
A)

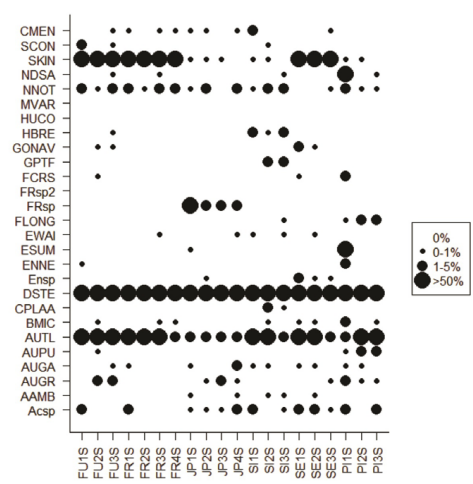

B)

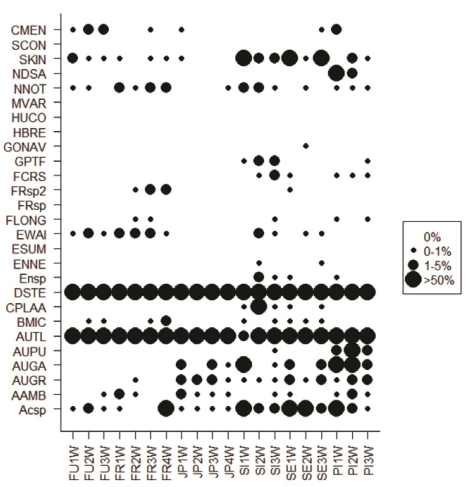

C)

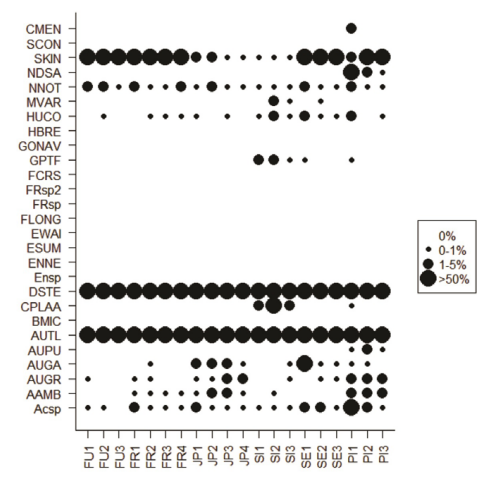

Figure 2. Distribution in samples and relative abundance of diatoms (coded according to OMNIDIA) from Cachoeira da Fumaça (FU), Cachoeira do França (FR), Jurupará (JP), Salto do Iporanga (SI), Serraria (SE) and Paineiras (PI) reservoirs. (A) Phytoplankton (summer), (B) Phytoplankton (winter) and (C) Surface Sediment. The numbers refer to the sampling stations. 

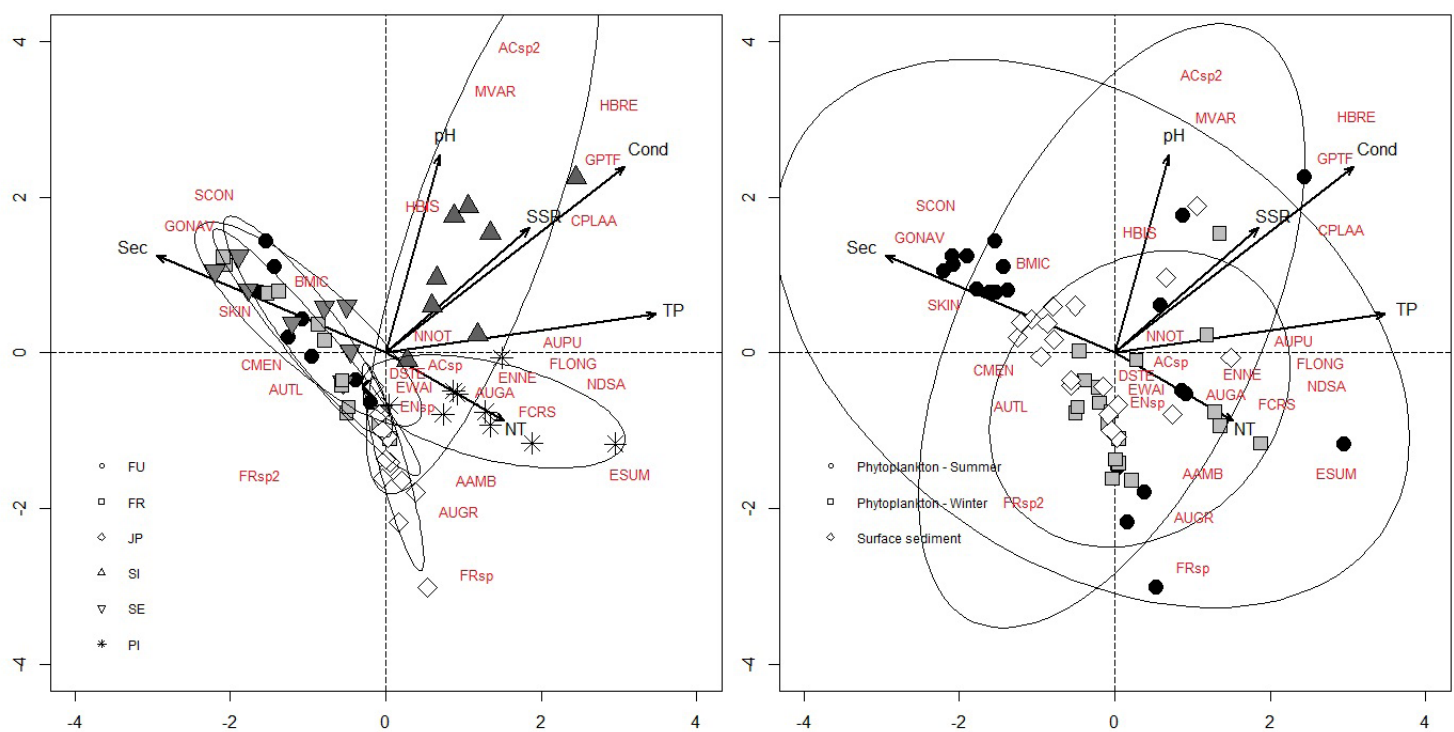

Figure 3. CCA ordination biplots of the Cachoeira da Fumaça (FU), Cachoeira do França (FR), Jurupará (JP), Salto do Iporanga (SI), Serraria (SE) and Paineiras (PI) reservoirs (A) and phytoplankton (summer and winter) and surface sediment. Confidence ellipses $(\alpha=0.95)$ shown. Coded according to Table 2.

reservoirs interaction values were non-significant $(\mathrm{F}=0.88 ; \mathrm{P}<0.5)$.

The stepwise selection of environmental variables retained six significant variables in decreasing importance, which influenced diatom distribution: TP, conductivity, $\mathrm{pH}, \mathrm{SSR}$, Secchi and TN. These variables accounted for about 36\% of the biological variation in the first two CCA axes. The intraset correlations indicated that TP and conductivity were the most significant contributors to axis 1, whereas $\mathrm{pH}$ and Secchi were the most significant contributors to axis 2 .

There was a trend in the separation of the sites according to the hydrological connectivity between the rivers of the systems (Figure 3A), and the ordination plot distinguished four main groups: the first group was represented by reservoirs located at the same watercourse (Cachoeira do França, Serraria and Cachoeira da Fumaça). This group had the highest abundance of Spicaticribra kingstonii (Figures 22-26, 99,102), Staurosira construens Ehrenberg (Figures 54-56, 122), Cyclotella cf. meneghiniana Kützing, Discostella stelligera (Figures 13-16, 97-98), Brachysira microcephala (Grunow) Compère (Figures 73-75, 123), Gomphonema naviculoides W. Smith (Figures 94-96), Achnanthidium tropicocatenatum Marquardt, C.E.Wetzel \& Ector (Figures 62-64, 117-119), Encyonema sp. (Figures 87-89, 130-131), Fragilaria billingsii Wengrat, C.E. Wetzel \& E.Morales (Figures 40-42), Eunotia waimiriorum C.E.Wetzel (Figures 48-51, 121) and Aulacoseira tenella (Figures 9-12, 100-101, 103-104), correlated to the Secchi vector, to the plankton during the summer and to the surface sediments habitat.

The second group was composed of the Salto do Iporanga reservoir especially associated with the highest values of conductivity, $\mathrm{TP}, \mathrm{pH}$ and soluble reactive silica (SRS). Regardless of the habitat, the most correlated species in this group were the benthic ones: Achnanthidium sp. (Figures 57-61, 113-116), Cocconeis cf. lineata (Ehrenberg) Van Heurck (Figures 52-53, 120), Humidophila brekkaensis (Figures 65-69, 111-112), H. biscutella (Figure 107), Navicula notha J.H.Wallace (Figures 78-79, 129), Melosira varians C.Agardh (Figures 27-29) and Geissleria punctifera (Hustedt) Metzeltin et al. (Figures 76-77, 127).

Finally, the third group featured in the biplot consisted mainly of the Jurupará and Paineiras reservoirs, which were correlated to the total nitrogen (NT) vector and lowest conductivity and Secchi values. The associated species in this group were Cyclotella cf. meneghiniana (Figures 17-21), Aulacoseira ambigua (Grunow) Simonsen (Figures 36-37, 109), A. granulata (Ehrenberg) Simonsen (Figures 34-35, A. pusilla (F.Meister) Tuji \& Houki (Figures 4-8, 105-106), A. granulata var. angustissima (O.Müller) Simonsen (Figures 38-39, 108), Sellaphora sassiana (Figures 80-83, 124), Encyonopsissubminuta Krammer \& E.Reichardt (Figures 84-86, 126), Encyonema neomesianum Krammer (Figures 90-93, 132), Fragilaria longifusiformis subsp. eurofusiformis 
Table 2. List of diatom taxa identified from the reservoirs ( $>2 \%$ relative abundance). Morphometric and meristic limits and ecology according to the literature. D: diameter $(\mu \mathrm{m})$; L: length $(\mu \mathrm{m})$; W: width $(\mu \mathrm{m})$; SH: semi cell height $(\mu \mathrm{m})$; S: striae in $10 \mu \mathrm{m}$; A: areolae in $10 \mu \mathrm{m}$; LN: lineolae in $10 \mu \mathrm{m}$.

\begin{tabular}{|c|c|c|c|}
\hline Taxon & Figures & Code & $\begin{array}{l}\text { Metric }(\mu \mathrm{m}) \& \text { meristic } \\
\quad(\text { in } 10 \mu \mathrm{m}) \text { limits }\end{array}$ \\
\hline \multicolumn{4}{|l|}{ AULACOSEIRACEAE } \\
\hline Aulacoseira ambigua (Grunow) Simonsen & $36-37,109$ & AAMB & SH: 12.7-14.4; D: 5.4-5.5; A: 14-16 \\
\hline $\begin{array}{l}\text { A. granulata var. angustissima (O.Müller) } \\
\text { Simonsen }\end{array}$ & $38-39,108$ & AUGA & SH: 16.6-18.7; D: 2.8-3; S: 16 \\
\hline $\begin{array}{l}\text { A. granulata (Ehrenberg) Simonsen } \\
\text { var. granulata }\end{array}$ & $34-35$ & AUGR & SH: 18.4-20,3; D: 7.3-7.6; A: 12 \\
\hline A. pusilla (F.Meister) Tuji \& Houki & $4-8,105-106$ & AUPU & SH: 3.3 ; D: 5.2-6.1 \\
\hline A. tenella (Nygaard) Simonsen & $\begin{array}{l}9-12,100-101 \\
103-104\end{array}$ & AUTL & SH: 2-2.6; D: 6.6-6.9 \\
\hline \multicolumn{4}{|l|}{ STEPHANODISCACEAE } \\
\hline Cyclotella cf. meneghiniana Kützing & $17-21$ & CMEN & D: $6.9-13.2 ; \mathrm{S}: 14$ \\
\hline $\begin{array}{l}\text { Discostella stelligera (Cleve \& Grunow) } \\
\text { Houk \& Klee }\end{array}$ & $\begin{array}{l}13-16,30-33 \\
97-98\end{array}$ & DSTEL & D: 7.2-17.3; S: 11-15; A: 32 \\
\hline $\begin{array}{l}\text { Spicaticribra kingstonii J.R.Johansen, } \\
\text { Kociolek \& R.L.Lowe }\end{array}$ & $22-26,99,102$ & SKIN & D: $8.1-16.2$ \\
\hline \multicolumn{4}{|l|}{ MELOSIRACEAE } \\
\hline Melosira varians C.Agardh & $27-29$ & MVAR & SH: 12.7-13.7; D: 21.1 \\
\hline \multicolumn{4}{|l|}{ FRAGILARIACEAE } \\
\hline $\begin{array}{l}\text { Fragilaria billingsii Wengrat, C.E.Wetzel \& } \\
\text { E.Morales }\end{array}$ & $40-42$ & FRsp2 & L: 56.2-62.7 ; W: 2.5-2.7; S: 21 \\
\hline $\begin{array}{l}\text { F. fusa (R.M.Patrick) Wengrat, C.E.Wetzel } \\
\text { \& E.Morales }\end{array}$ & $43-44$ & FRsp & L: 78.8-87.1; W: 2.8-3; S: 17-18 \\
\hline $\begin{array}{l}\text { Fragilaria longifusiformis subsp. } \\
\text { eurofusiformis Lange-Bertalot \& S.Ulrich }\end{array}$ & $45-47,110$ & FLONG & L: 58.1-90.6; W: 2.5-2.7; S: 35 \\
\hline $\begin{array}{l}\text { Staurosira construens Ehrenberg } \\
\text { ACHNANTHIDIACEAE }\end{array}$ & $54-56,122$ & SCON & L: 18-19.1; W: 9.7-10.7; S: 14-16 \\
\hline $\begin{array}{l}\text { Achnanthidium tropicocatenatum } \\
\text { Marquardt, C.E.Wetzel \& Ector }\end{array}$ & $62-64,117-119$ & ACsp & L: 17.7-18.2; W: 2.7; 3.1; S: 38; A: 50 \\
\hline *Achnanthidium sp. & $57-61,113-116$ & ACsp2 & L: 12-17.5; W: 3.1-3.5; S: 32 ; A: 50 \\
\hline $\begin{array}{l}\text { Cocconeis cf. lineata (Ehrenberg) Van } \\
\text { Heruck }\end{array}$ & $52-53,120$ & CPLAA & L: 29.7-35.2; W: 15.4-15.9; S: 16 \\
\hline \multicolumn{4}{|l|}{ EUNOTIACEAE } \\
\hline $\begin{array}{l}\text { Eunotia waimiriorum C.E.Wetzel } \\
\text { CYMBELLACEAE }\end{array}$ & \multicolumn{2}{|c|}{ CYMBELLACEAE } & L: 16.7-36.2; W: 1.5-2.2; S: 20 \\
\hline Encyonema neomesianum Krammer & $90-93,132$ & ENNE & L: 36.9-30; W: 7.9-8.4; S: 11-13; A: 32 \\
\hline Encyonema sp. & $87-89,130-131$ & ENsp & $\begin{array}{c}\mathrm{L}: 19.8-20.9 ; \mathrm{W}: 5.3-4.7 ; \mathrm{S}: 10-12 \\
\text { A: } 40\end{array}$ \\
\hline $\begin{array}{l}\text { Encyonopsis subminuta Krammer \& } \\
\text { E.Reichardt }\end{array}$ & $84-86,126$ & ESUM & L: 20.1-22.5; W: 4; S: 25-26; A: 40 \\
\hline \multicolumn{4}{|l|}{ GOMPHONEMATACEAE } \\
\hline $\begin{array}{l}\text { Geissleria punctifera (Hustedt) } \\
\text { Metzeltin et al. }\end{array}$ & $76-77,127$ & GPTF & L: 20.8-26.2; W: 6.2-6.6; S: 16-18 \\
\hline Gomphonema naviculoides W.Smith & $94-96$ & GONAV & L: 41.7-43.1; W: 7.9-8.2; S: 14-15 \\
\hline $\begin{array}{l}\text { *Humidophila brekkaensis (J.B.Petersen) } \\
\text { R.L.Lowe et al. }\end{array}$ & $65-69,111-112$ & HBRE & L: 9.8-15.2; W: 3.1-3.3; S: 34-35 \\
\hline $\begin{array}{l}{ }^{* *} H . \text { biscutella (Moser, Lange-Bertalot \& } \\
\text { Metzeltin) Lowe et. al. }\end{array}$ & 107 & HBIS & L: 9.42; W: 2.6; S: 35 \\
\hline \multicolumn{4}{|l|}{ BRACHYSIRACEAE } \\
\hline $\begin{array}{l}\text { Brachysira microcephala (Grunow) } \\
\text { Compère }\end{array}$ & $73-75,123$ & BMIC & L: 24.1-26.8; W: 5.1-5.3; S: 37; A: 30 \\
\hline \multicolumn{4}{|l|}{ AMPHIPLEURACEAE } \\
\hline $\begin{array}{l}\text { Frustulia crassinervia (Brébisson ex Smith) } \\
\text { Lange-Bertalot \& Krammer }\end{array}$ & $70-72,125,128$ & FRCS & L: 45.9-48; W: 9.9-10.1; S: 34; A: 36 \\
\hline Navicula notha J.H.Wallace & $78-79,129$ & NNOT & L: 27.4-33.1; W: 5.4-5.7; S: 10; LN: 24 \\
\hline
\end{tabular}

Taxa preceded by one asterisk $\left(^{*}\right)$ represent new records for the state of Sáo Paulo, and those preceded by two asterisks $\left({ }^{* *}\right)$ are first citations for Brazil. 
Table 2. Continued...

\begin{tabular}{lccc}
\multicolumn{1}{c}{ Taxon } & Figures & Code & $\begin{array}{c}\text { Metric }(\boldsymbol{\mu m}) \text { \& meristic } \\
\text { (in 10 } \boldsymbol{\mu m} \text { ) limits }\end{array}$ \\
\hline $\begin{array}{l}\text { SELLAPHORACEAE } \\
\text { *Sellaphora sassiana (Metzeltin \& } \\
\text { Lange-Bertalot) C.E.Wetzel }\end{array}$ & $80-83,124$ & NDSA & L: 14-14.5; W: 4.6-4.7; S: 14-20; A: 35 \\
\hline
\end{tabular}

Taxa preceded by one asterisk $\left(^{*}\right)$ represent new records for the state of São Paulo, and those preceded by two asterisks $\left({ }^{* *}\right)$ are first citations for Brazil.
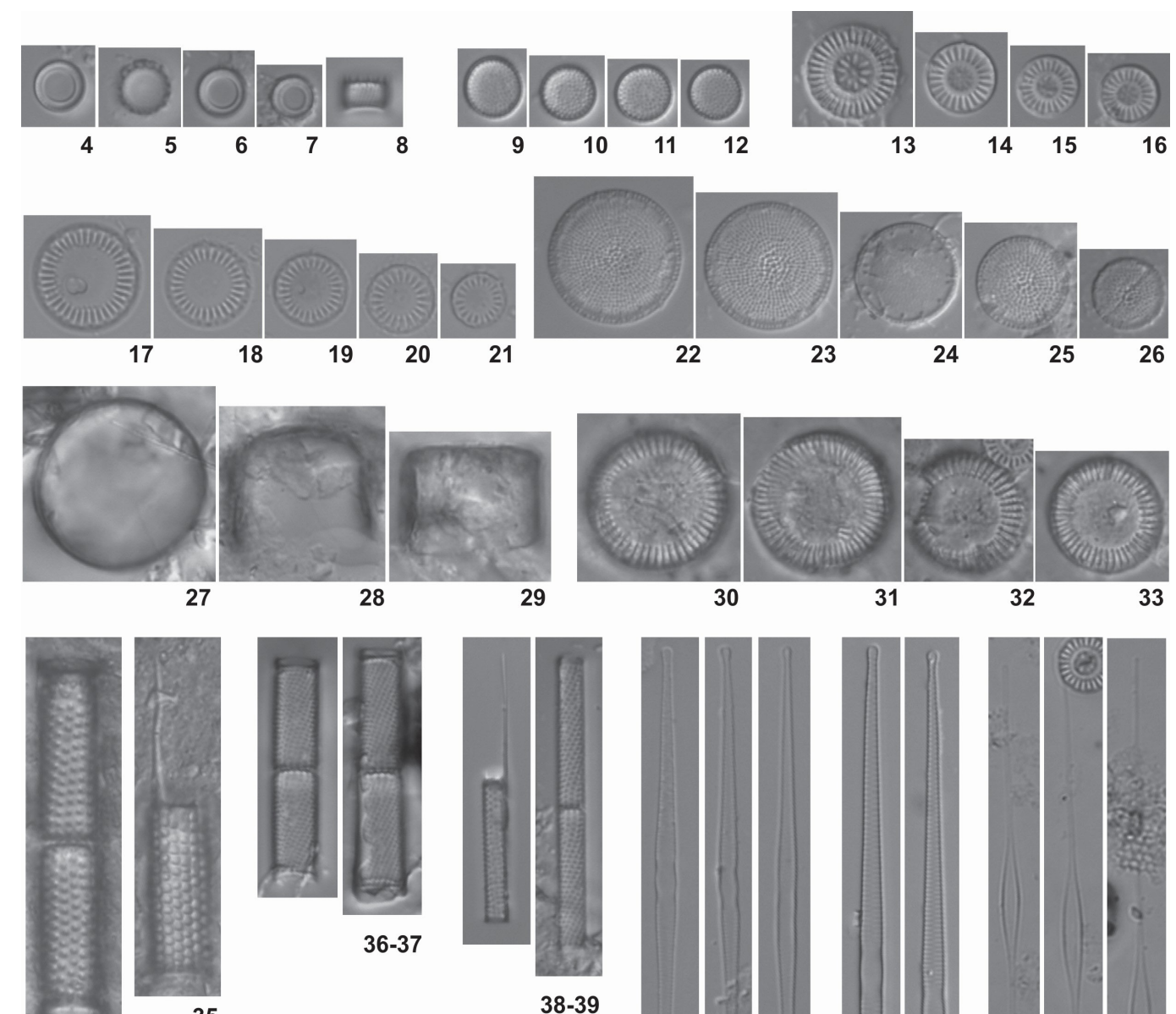

35

36-37
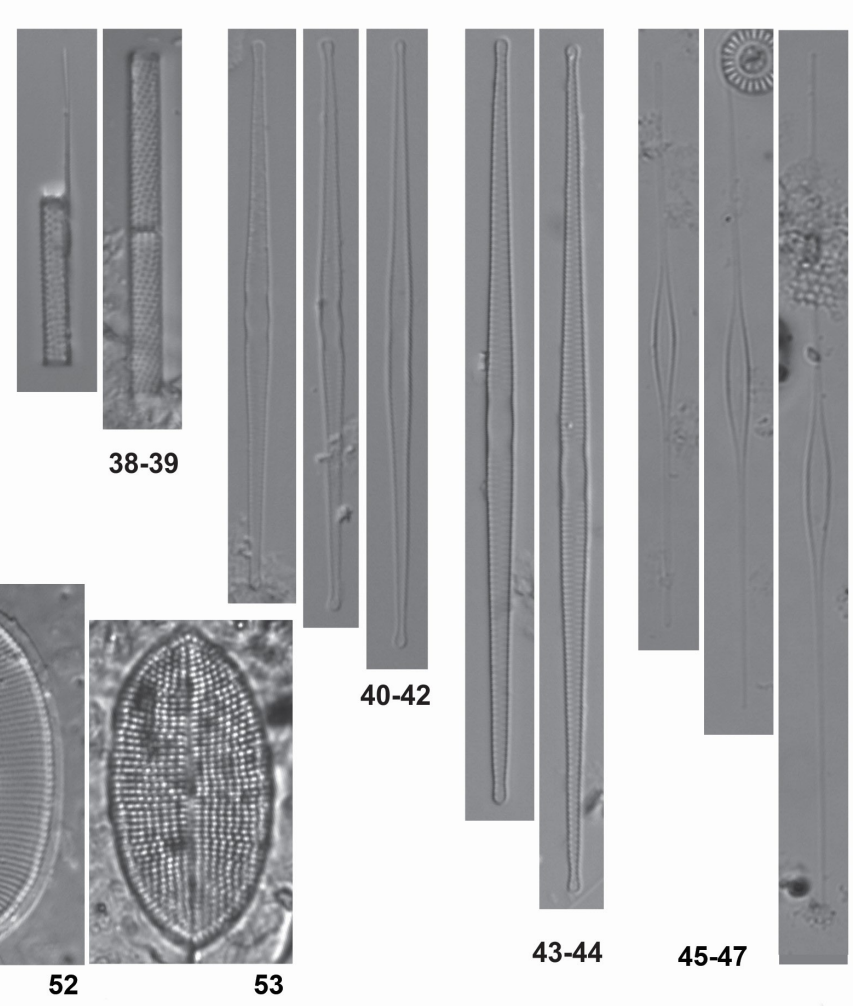

$\begin{array}{llll}48 & 49 & 50 & 51\end{array}$

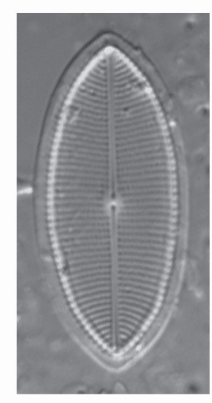

52

53

Figures 4-53. Diatom assemblages (Bacillariophyta) in six tropical reservoirs (São Paulo, Brazil). LM views. 4-8. Aulacoseira pusilla. 9-12. Aulacoseira tenella. 13-16. Discostella stelligera. 17-21. Cyclotella cf. meneghiniana. 22-26. Spicaticribra kingstonii. 27-29. Melosira varians. 30-33. Discostella stelligera, initial cells. 34-35. Aulacoseira granulata. 36-37. Aulacoseira ambigua. 38-39. Aulacoseira granulata var. angustissima. 40-42. Fragilaria billingsii. 43-44. Fragilaria fusa. 45-47. Fragilaria longifusiformis subsp. eurofusiformis Lange-Bertalot \& S.Ulrich. 48-51. Eunotia waimiriorum. 52-53. Cocconeis cf. lineata. 52. Raphe valve. 53. Rapheless valve. Scale bar: $10 \mu \mathrm{m}$. 

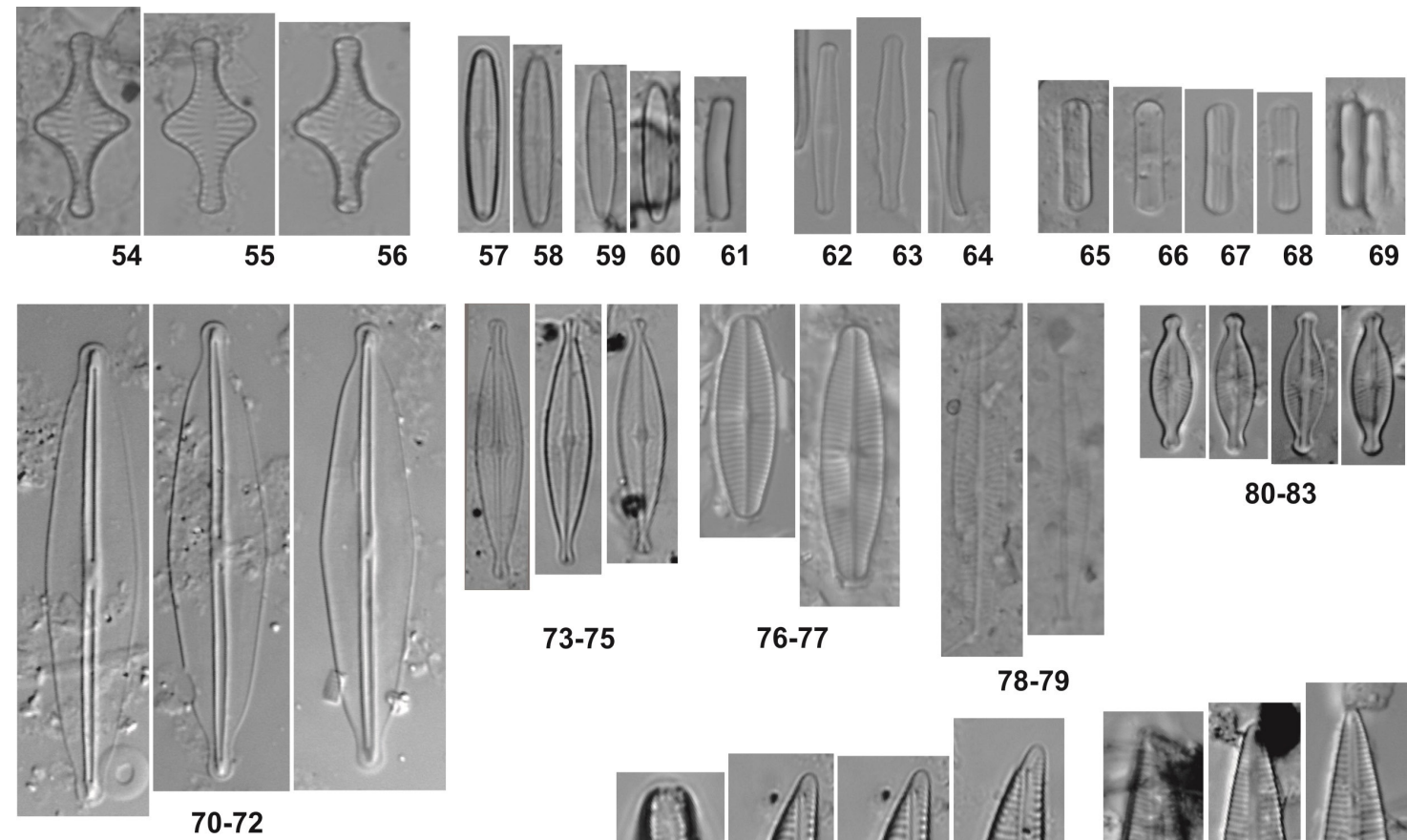

73-75
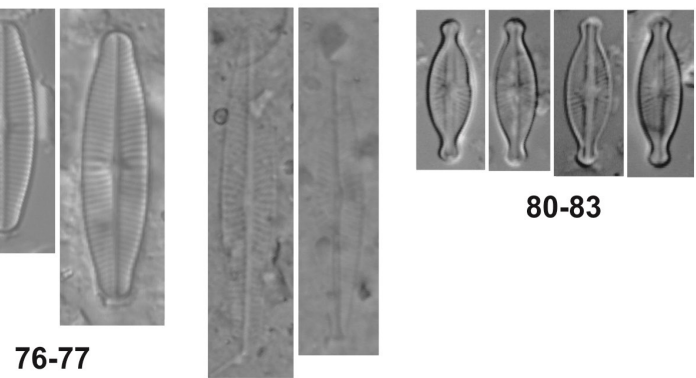

$80-83$

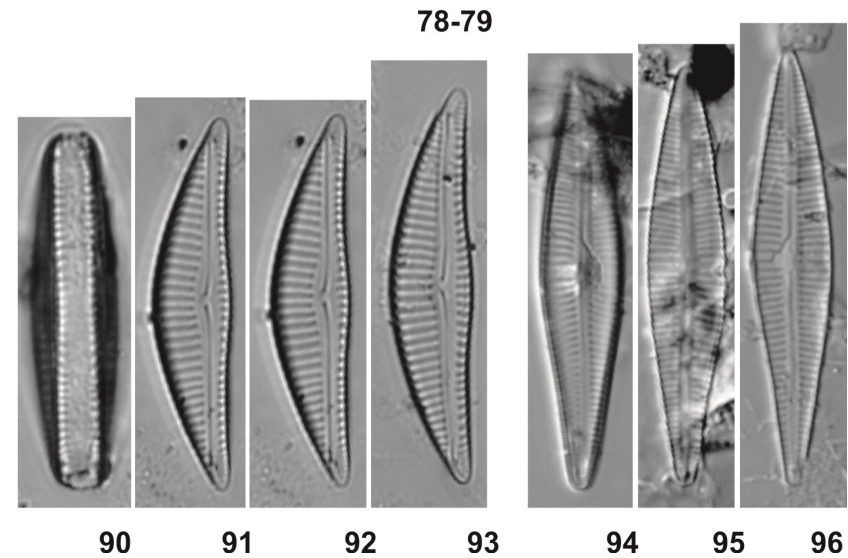

Figures 54-96. Diatom assemblages (Bacillariophyta) in six tropical reservoirs (São Paulo, Brazil). LM views. 54-56. Staurosira construens. 57-61. Achnanthidium sp. 57-58. Raphe valve. 59-60. Rapheless valve. 61. Girdle view. 62-64. Achnanthidium tropicocatenatum. 62. Raphe valve. 63. Rapheless valve. 64. Girdle view. 65-69. Humidophila brekkaensis. 69. Girdle views. 70-72. Frustulia crassinervia. 73-75. Brachysira microcephala. 76-77. Geissleria punctifera. 78-79. Navicula notha. Figs 80-83. Sellaphora sassiana. 84-86. Encyonopsis subminuta. 87-89. Encyonema sp. 90-93. Encyonema neomesianum. 90. Girdle view. 94-96. Gomphonema naviculoides. Scale bar: $10 \mu \mathrm{m}$.

Lange-Bertalot \& S.Ulrich (Figures 45-47, 110), Fragilaria fusa (R.M.Patrick) Wengrat, C.E. Wetzel $\&$ E.Morales (Figures 43-44) and Frustulia crassinervia (Brébisson ex Smith) Lange-Bertalot \& Krammer (Figures 70-72, 125, 128). These species are known for their planktonic habit and they showed the greatest relative abundance during the winter, in which the water column is in a mixing regime.

\section{Discussion}

Studies about limnological characteristics for the studied region are extremely rare, especially those considering seasonal and spatial influence. Most of them are restricted to reports on water sources that focus on the characterization of the conservation unit (CETEC, 2000) and to the PEJU Management
Plan (Fundação Florestal do Estado de São Paulo), which covers the water sources inserted in the Park area. Among others, there are some studies regarding the surface water quality (Cetesb, Companhia Ambiental do Estado de São Paulo) besides reports organized by the Companhia Brasileira de Alumínio (CBA), which operates eight plants in the Ribeira de Iguape basin. Concerning the Paineiras reservoir, only one survey was found: an unpublished doctoral dissertation whose theme is the adaptation of the fish assembly index in reservoirs along the Turvo River (SP) (Ferreira, 2011).

The currently measured limnological characteristics of the reservoirs indicate that the systems are under relatively protected conditions, with low anthropogenic impact, promoted by their insertion in the PEJU preservation area. 


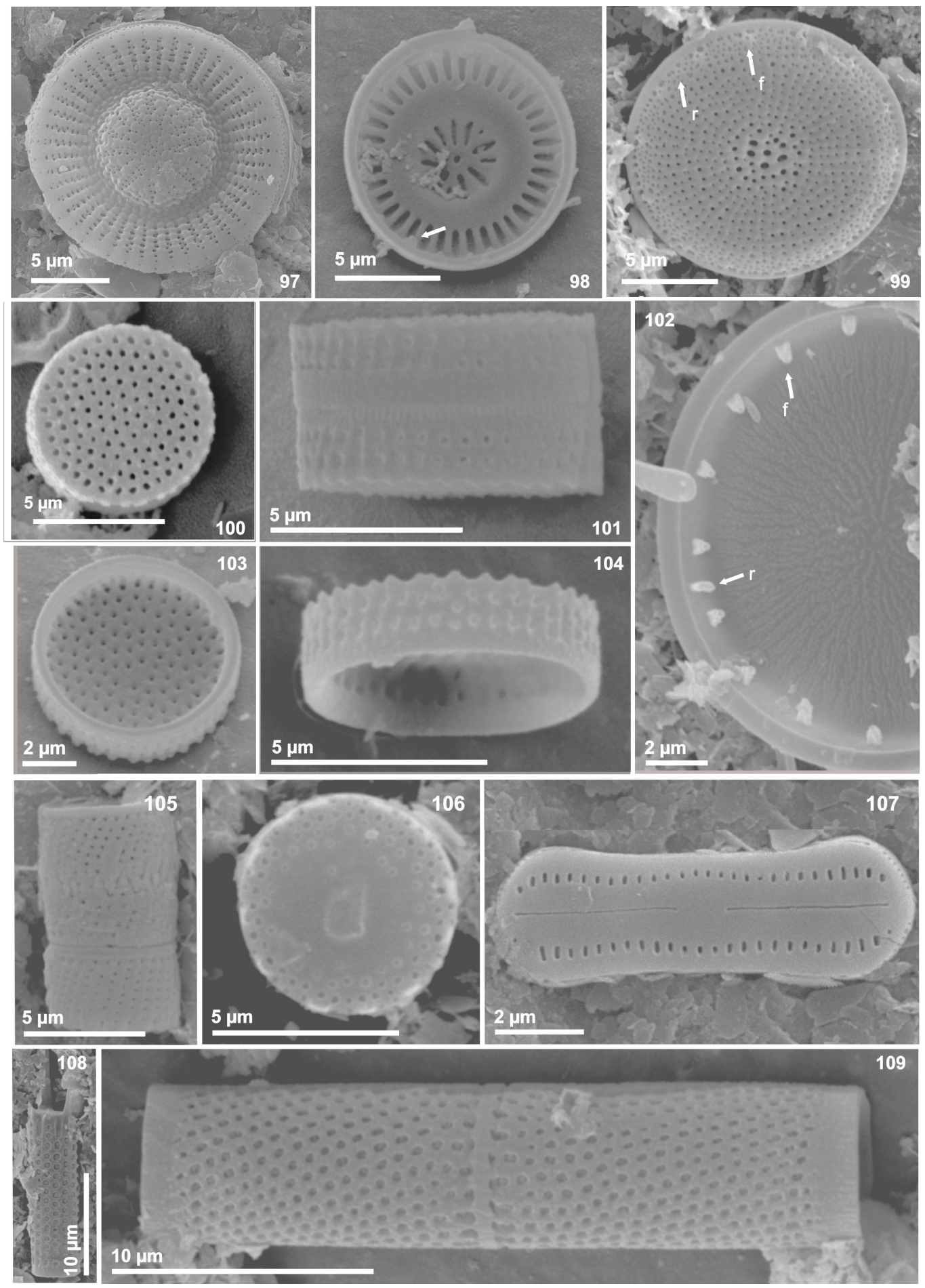

Figures 97-109. Diatom assemblages (Bacillariophyta) in six tropical reservoirs (São Paulo, Brazil). SEM views. 97-98. Discostella stelligera. 97. External valve view with details of the convex central area. 98. Internal valve view with convex central area and alveolate stellate pattern. Note marginal fultoportulae between every costae. 99, 102. Spicaticribra rudis. 99. External valve view with larger central areolae. Note position of rimoportula (arrow r) and fultoportulae (arrow f). 102. Internal valve view. Note position of rimoportula (arrow r) and fultoportulae (arrow f). 100-101, 103-104. Aulacoseira tenella. 100. External valve view. Flat valve face with small areolae. 101. Frustule in girdle view showing the straight, inclined to the right (dextrorse) areolae. 103. Internal valve view. 104. Detail of the mantle areolae and very short spines. 105-106. Aulacoseira pusilla. 105. External girdle view. Note the short spines located at the end of each two pervalvar costae. 106. Valve face. 107. Humidophila biscutella. External valve view. 108. Aulacoseira granulata. Valve view of the terminal cell of chain and a very long spine. 109. Aulacoseira ambigua. Girdle view of two valves. Note the fascia. Scale bars: Figs 97-101, 104-106: $5 \mu \mathrm{m}$; Figs 102-107: $2 \mu \mathrm{m}$; Figs 108, $109: 10 \mu \mathrm{m}$. 


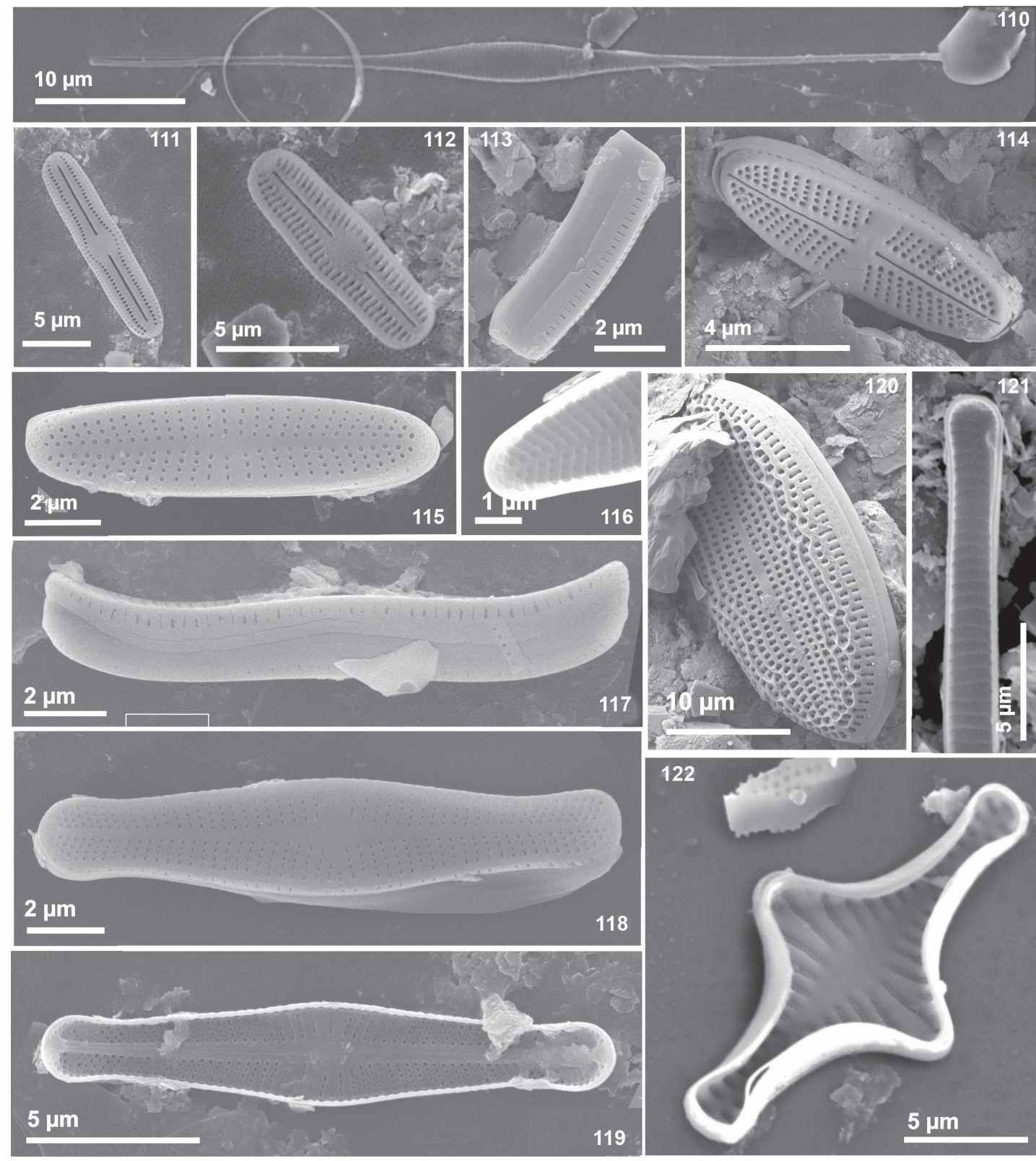

Figures 110-122. Diatom assemblages (Bacillariophyta) in six tropical reservoirs (São Paulo, Brazil). SEM. 110. Fragilaria longifusiformis subsp. eurofusiformis Lange-Bertalot \& S.Ulrich. Internal valve view. 111-112. Humidophila brekkaensis. 111. Internal valve view. 112. External valve view. 113-116. Achnanthidium sp. 113. Girdle view. Fig. 114. External view of raphe valve. Fig. 115. External view of rapheless valve. Fig. 116. Internal view of rapheless valve. 117-119. Achnanthidium tropicocatenatum. 117. Girdle view. 118. External view of rapheless valve. 119. Internal view of raphe valve. 120. Cocconeis cf. lineata. External view of rapheless valve. Fig. 121. Eunotia waimiriorum. Internal valve view. 122. Staurosira construens. Internal valve view. Scale bars: Figs 110, $120: 10 \mu \mathrm{m}$; Figs 111, 112, 119, 121, 122: $5 \mu \mathrm{m}$; Figs 113, 115, 117, 118: $2 \mu \mathrm{m}$; Fig. 114: $4 \mu \mathrm{m}$; Fig. 116: $1 \mu \mathrm{m}$.

Low concentrations of nutrients in their dissolved forms as well as TN and TP values measured in this study are typical of oligotrophic and mesotrophic environments (Tundisi, 2006; Vercellino \& Bicudo, 2006). However, despite the nutrients played an important role in the diatom community variation, the hydrological connectivity role should not be neglected.
According to the currently calculated TSI, reservoirs in the same watercourse included in the first group showed a better water quality (ultraoligotrophic and oligotrophic) when compared to the second and third groups (mostly mesotrophic) (Table 1). However, it is important to note that there was not a large trophic gradient in the study area, and these eutrophic sites are probably 


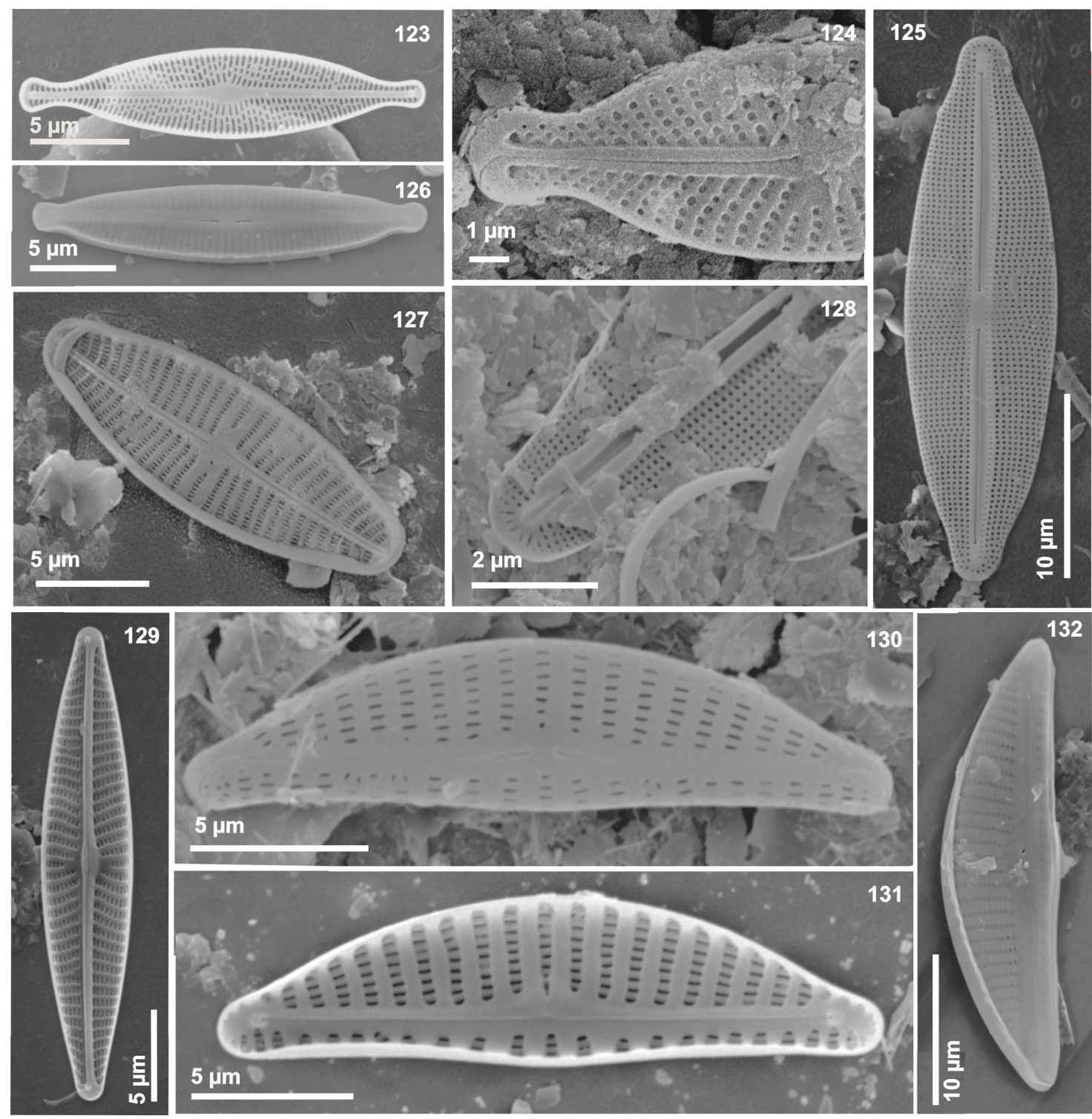

Figures 123-132. Diatom assemblages (Bacillariophyta) in six tropical reservoirs (São Paulo, Brazil). SEM views. 123. Brachysira microcephala. Internal valve view. 124. Sellaphora sassiana. External valve view. 125, 128. Frustulia crassinervia. 125. External valve view. 128. Internal valve view. 126. Encyonopsis subminuta. External valve view. 127. Geissleria punctifera. Internal valve view. 129. Navicula notha. Internal valve view. 130-131. Encyonema sp. 130. External valve view. 131. Internal valve view. 132. Encyonema neomesianum. External

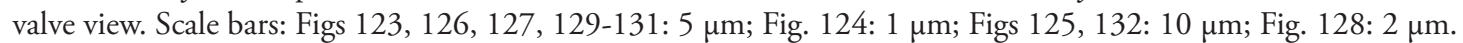

a result of the system anthropic management during the sampling period.

Regarding ecological preference trends of species, our results agree with those found in the literature, with most of the species having been reported in Brazilian reservoirs and oligotrophic environments. Occurring on Cachoeira do França, Cachoeira da Fumaça and Serraria reservoirs (first group), Achnanthidium tropicocatenatum was found in alkaline waters of good quality and with low electrolyte content (Marquardt et al., 2017b).
Because of the wide morphological variation, the Spicaticribra kingstonii species complex might be a species flock (Tuji et al., 2012). Also, S. rudis is frequently reported to the Brazilian southern, southeastern and northeastern regions, found in high temperatures and low conductivity waters (Ludwig et al., 2008); this species occurred in the mesotrophic Paraitinga reservoir (Rocha, 2012), and was abundant in the ultra-oligotrophic Jaguari reservoir (Nascimento, 2012) as well those located along the Paranapanema River (Fontana \& Bicudo, 
2009). Also, Staurosira construens is considered an alkaliphilous and meso-eutraphentic taxon (van Dam et al., 1994; Morales, 2006), registered in the plankton and periphyton in rivers from the Southern region of Brazil (e.g. Flôres et al., 1999; Landucci \& Ludwig, 2005) besides an oligotrophic reservoir in São Paulo State (Barbosa, 2012). A further species related to the first group, Discostella stelligera is considered tolerant to nutrient enrichment (Stoermer, 1978). In Brazilian reservoirs, the species was recorded by Faustino et al. (2016) in the Guarapiranga reservoir in mesotrophic to super-eutrophic conditions in $37 \%$ of samples. Recent studies suggested that this taxon is part of a key group of diatoms that are frequently dominant members of phytoplankton communities in low to moderate-productivity lakes, and that processes that modify light availability (such as water transparence and water column stability) and nutrient concentration are likely to play a major role in controlling the growth of small centric diatoms in Arctic lakes (Saros \& Anderson, 2015). In addition, Gomphonema naviculoides is particularly prevalent in the Tropics and also in North America; to date, this species has been identified as G. gracile Ehrenberg (Reichardt, 2015). According to the latest revision of the complex involving Gomphonema gracile, the species tolerates low salt concentration (Reichardt, 2015). Aulacoseira tenella, typically associated with oligotrophic and oligo-mesotrophic reservoirs (Bicudo et al., 2016), has been recorded in Brazil lotic ecosystems (Landucci \& Ludwig, 2005), with low conductivity reservoirs (Raupp et al., 2006; EskinaziLeça et al., 2010; Silva et al., 2010; Nascimento, 2012), as well as in acidophilic (Camburn \& Charles, 2000) and oligotrophic environments (Siver \& Kling, 1997). Fragilaria billingsii is commonly found in São Paulo State reservoirs, living in slightly acidic waters with moderate to high nutrient enrichment (Wengrat et al., 2016). Finally, Eunotia waimiriorum is a common colonial planktonic diatom from oligotrophic pristine rivers and streams in the Amazon hydrographical basin (Wetzel et al., 2010).

Among the diatoms related to the Salto do Iporanga reservoir (second group), Navicula notha is considered a cosmopolitan species, present in oligotrophic environments with low conductivity, slightly acid to near neutral water (Lange-Bertalot, 2001). Geissleria punctifera was considered tolerant to the pollution conditions on rivers and streams in Maringá (Paraná State, Brazil), and was an abundant periphytic diatom in three streams with different anthropic influences (Moresco et al., 2011). Centric diatoms as Melosira varians prefer low light availability conditions. This species is frequent and abundant in environments with vertical column mixing water (Reynolds et al., 2002), and has high nutrient requirements and high disturbance tolerance (B-Béres et al., 2014).

Humidophila brekkaensis is reported for the first time in Sáo Paulo State, and had strong correlation to the $\mathrm{pH}$ and conductivity vectors. This species was registered in lotic environments from southern Brazil (Oliveira et al., 2002).

Mostly taxa correlated to the Jurupará and Paineiras reservoirs (third group) were 'araphid' and 'centric' ones. Our studies corroborate Bicudo et al. (2016) in an ecological study focused on Aulacoseira from São Paulo State. In this study, species such as Aulacoseira ambigua and A. granulata were also associated to the water mixing and low light conditions (Houk, 2003; Taylor et al., 2007) showing higher abundances in colder (winter), slightly acid waters. In the same way, $A$. granulata var. angustissima was associated to environments with higher TN concentration. The araphid Fragilaria longifusiformis subsp. eurofusiformis is distributed in freshwater localities in at least two continents from the northern hemisphere, including ponds, lakes, reservoirs and rivers over a wide range of trophic conditions (Morales \& Manoylov, 2006). In USA, latter taxa were lacking from the most acidic habitats in both regions, and were most often observed in relatively dilute waters with a specific conductivity below $200 \mu \mathrm{S} \mathrm{cm}^{-1}$ (Morales \& Manoylov, 2006). Finally, Frustulia crassinervia, considered a species that occurs in oligotrophic environments (van Dam et al., 1994) is a characteristic member of phytobenthos in acid, peaty waters (such as Sphagnum bogs), and many ephemeral habitats (Krammer \& Lange Bertalot, 1986; Round et al., 1990; Veselá et al., 2012). Encyonema neomesianum, widely reported in São Paulo State (Marquardt \& Bicudo, 2014), is considered an oligotrophic taxon, with an optimum in alkaline waters (Moro \& Fürstenberger, 1997).

It is important to note that despite the limited understanding from theory of how factors interact to affect species distribution, there are two important aspects of the landscape spatial structure susceptible to impact the strength of species-sorting: the connectivity matrix (i.e. the spatial arrangement among localities and dispersal rate among them) and the environmental heterogeneity (i.e. variance and range of environmental conditions and their 
spatial autocorrelation) (Ai et al., 2013). Approaches concerning the significance of relationships among the biological, environmental and spatial datasets in the systems currently studied can be found in Marquardt et al. (2017a).

\section{Conclusions}

This study provided new information on the ecology and distribution of tropical diatoms. Three potential water quality indicator diatom groups were outlined, which indicated oligotrophic conditions, water mixing with low light conditions, and species with higher nutrient requirements occurring in higher conductivity and $\mathrm{pH}$ waters, in agreement with those already reported in the literature. We reinforce the Parque Estadual do Jurupará (PEJU, Jurupará State Park) importance for the ecological quality maintenance of the reservoirs and reference conditions for the São Paulo Metropolitan Region water sources.

\section{Acknowledgements}

This study was carried out within the framework of the AcquaSed project supported by funds from FAPESP (Fundação de Amparo à Pesquisa do Estado de São Paulo, grant no 2009/53898-9), and was undertaken as part of GCM thesis at the Instituto de Botânica, São Paulo, Brazil (FAPESP doctoral fellowship no 2013/10314-2). CEMB thanks CNPq (Conselho Nacional de Desenvolvimento Científico e Tecnológico) for Research Fellowship (no 305031/2016-3). We deeply appreciate the valuable assistance of personnel from the Votorantim Energia for their valuable logistical support during the fieldwork.

\section{References}

AI, D., GRAVEL, D., CHU, C. and WANG, G. Spatial structures of the environment and of dispersal impact species distribution in competitive metacommunities. PLoS One, 2013, 8(7), e68927. http://dx.doi.org/10.1371/journal.pone.0068927. PMid:23874815.

ALMEIDA, P.D. and BICUDO, D.C. Diatomáceas planctônicas e de sedimento superficial em represas de abastecimento da Região Metropolitana de São Paulo, SP, Sudeste do Brasil. Hoehnea, 2014, 41(2), 187-207. http://dx.doi.org/10.1590/S223689062014000200004

ALMEIDA, P.D., MORALES, E.A., WETZEL, C.E., ECTOR, L. and BICUDO, D.C. Two new diatoms in the genus Fragilaria Lyngbye (Fragilariophyceae) from tropical reservoirs in Brazil and comparison with type material of F. tenera. Phytotaxa, 2016,
246(3), 163-183. http://dx.doi.org/10.11646/ phytotaxa.246.3.1.

ALMEIDA, P.D., WETZEL, C.E., MORALES, E.A., ECTOR, L. and BICUDO, D.C. Staurosirella acidophila sp. nov., a new araphid diatom (Bacillariophyta) from southeastern Brazil: ultrastructure, distribution and autecology. Cryptogamie. Algologie, 2015, 36(3), 255-270. http:// dx.doi.org/10.7872/crya/v36.iss3.2015.255.

AMERICAN PUBLIC HEALTH ASSOCIATION APHA. Standard methods for the examination of water and wastewater. Washington: American Public Health Association, 2005.

BARBOSA, V.S. Ecologia de diatomáceas do Reservatório Cabuçu, Guarulhos, SP-qualidade da água, sazonalidade e correlação com parâmetros físicos e químicos. Revista Geociências, 2012, 11(1), 5-18.

BARTOZEK, E.C.R., BUENO, N.C., LUDWIG, T.A.V., TREMARIN, P.I., NARDELLI, M.S. and ROCHA, A.C.R. Diatoms (Bacillariophyceae) of Iguaçu National Park, Foz do Iguaçu, Brazil. Acta Botanica Brasílica, 2013, 27(1), 108-123. http:// dx.doi.org/10.1590/S0102-33062013000100012.

BATTARBEE, R.W. Diatom analysis. In: B.E. BERGLUND, ed. Handbook of holocene paleoecology and paleohydrology. London: Wiley \& Sons, 1986, pp. 527-570.

B-BÉRES, V., TÖRÖK, P., KÓKAI, Z., KRASZNAI, E.T., TÓTHMÉRÉSZ, B. and BÁCSI, I. Ecological diatom guilds are useful but not sensitive enough as indicators of extremely changing water regimes. Hydrobiologia, 2014, 738(1), 191-204. http://dx.doi. org/10.1007/s10750-014-1929-y.

BERTOLLI, L.M., TREMARIN, P.I. and LUDWIG, T.A.V. Diatomáceas perifíticas em Polygonum hydropiperoides Michaux, reservatório do Passaúna, Região Metropolitana de Curitiba, Paraná, Brasil. Acta Botanica Brasilica, 2010, 24(4), 1065-1081. http:// dx.doi.org/10.1590/S0102-33062010000400022.

BES, D., ECTOR, L., TORGAN, L.C. and LOBO, E.A. Composition of the epilithic diatom flora from a subtropical river, Southern Brazil. Iheringia. Série Botânica, 2012, 67(1), 93-125.

BESSE-LOTOTSKAYA, A., VERDONSCHOT, P.F.M. and SINKELDAM, J.A. Uncertainty in diatom assessment: sampling, identification and counting variation. Hydrobiologia, 2006, 566(1), 247-260. http://dx.doi.org/10.1007/s10750-006-0092-5.

BICUDO, D.C., TREMARIN, P.I., ALMEIDA, P.D., ZORZAL-ALMEIDA, S., WENGRAT, S., FAUSTINO, S.B., COSTA, L.F., BARTOZEK, E.C.R., ROCHA, A.C.R., BICUDO, C.E.M. and MORALES, E.A. Ecology and distribution of Aulacoseira species (Bacillariophyta) in tropical reservoirs from Brazil. Diatom Research, 2016, 
31(3), 199-215. http://dx.doi.org/10.1080/026924 9X.2016.1227376.

BIRKS, H.J.B. Numerical methods for the analysis of diatom assemblage data. In: J.P. SMOL and E.F. STOERMER, eds. The Diatoms: applications for the environmental and earth sciences. 2nd ed. Cambridge: Cambridge University Press, 2010, pp. 23-54. http:// dx.doi.org/10.1017/CBO9780511763175.004.

BIRKS, H.J.B. The importance of pollen and diatom taxonomic precision in quantitative palaeoenvironmental reconstructions. Review of Palaeobotany and Palynology, 1994, 83(1-3), 107-117. http://dx.doi.org/10.1016/0034-6667(94)90062-0.

BOLLA, B., BORICS, G., KISS, K.T., RESKÓNÉ, N.M., VÁRBÍRÓ, G. and ÁCS, É. Recommendations for ecological status assessment of Lake Balaton (largest shallow lake of central Europe), based on benthic diatom communities. Vie et Milieu-Life and Environment, 2010, 60(3), 197-208.

CALIFORNIA ACADEMY OF SCIENCES. Catalogue of Diatom Names [online]. San Francisco, 2011 [viewed 1 Mar. 2017]. Available from: http:// researcharchive.calacademy.org/research/diatoms/ names/index.asp

CAMBURN, K.E. and CHARLES, D.F. Diatoms of low-alkalinity lakes in the Northeastern United States. Philadelphia: The Academy of Natural Sciences of Philadelphia, 2000, 152 p. Special Publication, 18.

CARNEIRO, L.A. and BICUDO, D.C. O gênero Lemnicola (Bacillariophyceae) no Estado de São Paulo, Brasil. Hoehnea, 2007, 34(2), 253-259. http:// dx.doi.org/10.1590/S2236-89062007000200010.

CAVALCANTE, K.P., TREMARIN, P.I. and LUDWIG, T.A.V. New records of amphoroid diatoms (Bacillariophyceae) from Cachoeira River, Northeast Brazil. Brazilian Journal of Biology = Revista Brasileira de Biologia, 2014, 74(1), 257 263. http://dx.doi.org/10.1590/1519-6984.24512. PMid:25055112.

CENTRO TECNOLÓGICO DA FUNDAÇÃO PAULISTA DE TECNOLOGIA E EDUCAÇÃO - CETEC. Diagnóstico da situação dos recursos hidricos do Ribeira de Iguape e Litoral Sul-UGRHI-11 [online]. São Paulo: CETEC, 2000 [viewed 8 May 2013]. Available from: http://www.sigrh.sp.gov.br/ sigrh/ARQS/RELATORIO/CRH/CBH-RB/847/ planoribeira\%20html.htm

CHÉTElAT, J., ClOUTIER, L. and AMYOT, M. Carbon sources for lake food webs in the Canadian High Arctic and other regions of Arctic North America. Polar Biology, 2010, 33(8), 1111-1123. http://dx.doi.org/10.1007/s00300-010-0797-9.

COSTA-BÖDDEKER, S., BENNION, H., JESUS, T.A., ALBUQUERQUE, A.L.S., FIGUEIRA, R.C.L. and BICUDO, D.C. Paleolimnologically inferred eutrophication of a shallow, tropical, urban reservoir in southeast Brazil. Journal of Paleolimnology, 2012., 48(4), 751-766. http://dx.doi.org/10.1007/ s10933-012-9642-1.

ESKINAZI-LEÇA, E., CUNHA, M.G.G.C., SANTIAGO, M.F., BORGES, G.C.P., LIMA, J.M.C., SILVA, M.H., LIMA, J.P. and MENEZES, M. Bacillariophyceae. In: R.C. FORZZA, J.F.A. BAUMGRATZ, C.E.M. BICUDO, A.A. CARVALHO JÚNIOR, A. COSTA, D.P. COSTA, M. HOPKINS, P.M. LEITMAN, L.G. LOHMANN, L.C. MAIA, G. MARTINELLI, M. MENEZES, M.P. MORIM, M.A.N. COELHO, A.L. PEIXOTO, J.R. PIRANI, J. PRADO, L.P. QUEIROZ, V.C. SOUZA, J.R. STEHMANN, L.S. SYLVESTRE, B.M.T. WALTER and D. ZAPPI, eds. Catálogo de plantas e fungos do Brasil. Vol. 1. Rio de Janeiro: Andrea Jakobsson Estúdio, Instituto de Pesquisas Jardim Botânico do Rio de Janeiro, 2010, pp. 262 309.

FARIA, D.M., TREMARIN, P.I. and LUDWIG, T.A.V. Diatomáceas perifíticas da represa Itaqui, São José dos Pinhais, Paraná: Fragilariales, Eunotiales, Achnanthales e Gomphonema Ehrenberg. Biota Neotropica, 2010, 10(3), 415-427. http://dx.doi. org/10.1590/S1676-06032010000300035.

FAUSTINO, S.B., FONTANA, L., BARTOZEK, E.C.R., BICUDO, C.E.M. and BICUDO, D.C. Composition and distribution of diatom assemblages from core and surface sediments of a water supply reservoir in southeastern Brazil. Biota Neotropica, 2016, 16(2), e20150129. http://dx.doi. org/10.1590/1676-0611-BN-2015-0129.

FERRARI, F. and LUDWIG, T.A.V. Coscinodiscophyceae, Fragilariophyceae e Bacillariophyceae (Achnanthales) dos rios Ivaí, São João e dos Patos, bacia hidrográfica do rio Ivaí, município de Prudentópolis, PR, Brasil. Acta Botanica Brasílica, 2007, 21(2), 421-441. http:// dx.doi.org/10.1590/S0102-33062007000200016.

FERREIRA, F.C. Adaptaçâo do indice de assembléia de peixes em Reservatórios (IAPR) às áreas das PCH's - usinas Batista e Jorda flor, rio turvo (SP) [Tese de Doutorado]. Rio Claro: Universidade Estadual Paulista, 2011.

FLÔRES, T.L., MOREIRA-FILHO, H. and LUDWIG, T.A.V. Contribuição ao inventário florístico das diatomáceas (Bacillariophyta) do Banhado de Taim, Rio Grande do Sul, Brasil: II. Fragilariaceae. Insula, 1999, 28, 167-187.

FONTANA, L. and BICUDO, D.C. Diatomáceas (Bacillariophyceae) de sedimentos superficiais dos reservatórios em cascata do Rio Paranapanema (SP/ PR, Brasil): Coscinodiscophyceae e Fragilariophyceae. Hoehnea, 2009, 36(3), 375-386. http://dx.doi. org/10.1590/S2236-89062009000300001.

FONTANA, L., ALBUQUERQUE, A.L.S., BRENNER, M., BONOTTO, D.M., SABARIS, T.P.P., PIRES, M.A.F., COTRIM, M.E.B. and BICUDO, D.C. 
The eutrophication history of a tropical water supply reservoir in Brazil. Journal of Paleolimnology, 2014, 51(1), 29-43. http://dx.doi.org/10.1007/s10933013-9753-3.

HOUK, V. Atlas of freshwater centric diatoms with a brief key and descriptions. Part I. Melosiraceae, Orthoseiraceae, Paraliaceae and Aulacoseiraceae. Czech Phycology, 2003, 1, 1-27. Supplement. 41 pls.

KIRETA, A.R., REAVIE, E.D., SGRO, G.V., ANGRADI, T.R., BOLGRIEN, D.W., HILL, B.H. and JICHA, T.M. Planktonic and periphytic diatoms as indicators of stress on great rivers of the United States: Testing water quality and disturbance models. Ecological Indicators, 2012, 13(1), 222-231. http://dx.doi.org/10.1016/j.ecolind.2011.06.006.

KOCIOLEK, J.P. Some thoughts on the development of a diatom flora for freshwater ecosystems in the continental United States and a listing of recent taxa described from U.S. freshwaters. Proceedings of the California Academy of Sciences Fourth Series, 2006, 57(21), 561-586.

KRAMMER, K. and LANGE-BERTALOT, H. Bacillariophyceae 1. Teil: Naviculaceae. In: H. ETTL, J. GERLOFF, H. HEYNIG and D. MOLLENHAUER, eds. Süßwasserflora von Mitteleuropa. Stuttgart: Gustav Fischer Verlag, 1986, pp. 1-876.

KRAMMER, K. The genus Pinnularia. In: H. LANGEBERTALOT, ed. Diatoms of Europe. Diatoms of the European Inland Waters and Comparable Habitats. Ruggell: A.R.G Gantner Verlag, 2000, pp. 1-703.

LAMPARELLI, M.C. Graus de trofia em corpos d'água do Estado de Sáo Paulo: avaliação dos métodos de monitoramento [Tese de Doutorado]. São Paulo: Universidade de São Paulo, 2004.

LANDUCCI, M. and LUDWIG, T.A.V. Diatomáceas de rios da bacia hidrográfica Litorânea, PR, Brasil: Coscinodiscophyceae e Fragilariophyceae. Acta Botanica Brasílica, 2005, 19(2), 345-357. http:// dx.doi.org/10.1590/S0102-33062005000200018.

LANGE-BERTALOT, H. Navicula sensu stricto. 10 Genera separated from Navicula sensu lato. Frustulia. In: H. LANGE-BERTALOT, ed. Diatoms of Europe. Diatoms of the European Inland Waters and Comparable Habitats. Ruggell: A.R.G Gantner Verlag K. G., 2001, pp. 1-526.

LANGE-BERTALOT, H., BĄK, M. and WITKOWSKI, A. Eunotia and some related genera. In: H. LANGEBERTALOT, ed. Diatoms of Europe. Diatoms of the European Inland Waters and Comparable Habitats. Ruggell: A.R.G Gantner Verlag K. G., 2011, pp. $1-747$.

LECOINTE, C., COSTE, M. and PRYGIEL, J. "Omnidia": software for taxonomy, calculation of diatom indices and inventories management.
Hydrobiologia, 1993, 269-270(1), 509-513. http:// dx.doi.org/10.1007/BF00028048.

LEGENDRE, P. and GALLAGHER, E.D. Ecologically meaningful transformations for ordination of species data. Oecologia, 2001, 129(2), 271-280. http://dx.doi. org/10.1007/s004420100716. PMid:28547606.

LUDWIG, T.A.V., TREMARIN, P.I., BECKER, V. and TORGA, L.C. Thalassiosira rudis sp. nov. (Coscinodiscophyceae): a new freshwater species. Diatom Research, 2008, 23(2), 389-399. http:// dx.doi.org/10.1080/0269249X.2008.9705765.

MARQUARDT, G.C. and BICUDO, C.E.M. Criptógamos do Parque Estadual das Fontes do Ipiranga, São Paulo, SP. Algas 36: Bacillariophyceae (Cymbellales). Hoehnea, 2014, 41(2), 209-246. http:// dx.doi.org/10.1590/S2236-89062014000200005.

MARQUARDT, G.C., BLANCO, S. and BICUDO, C.E.M. Distance decay as a descriptor of the diatom compositional variation in tropical reservoirs. Marine \& Freshwater Research, 2017a, 69(1), 105-113. http:// dx.doi.org/10.1071/MF17003.

MARQUARDT, G.C., COSTA, L.F., BICUDO, D.C., BICUDO, C.E.M., BLANCO, S., WETZEL, C.E. and ECTOR, L. Type analysis of Achnanthidium minutissimum and $A$. catenatum and description of $A$. tropicocatenatum sp. nov. (Bacillariophyta), a common species in Brazilian reservoirs. Plant Ecology and Evolution, 2017b, 150(3), 313-330. http:// dx.doi.org/10.5091/plecevo.2017.1325.

MARQUARDT, G.C., DA ROCHA, A.C.R., WETZEL, C.E., ECTOR, L. and BICUDO, C.E.M. Encyonema aquasedis sp. nov. and Kurtkrammeria salesopolensis $s p$. nov: two new freshwater diatom species (Cymbellales, Bacillariophyceae) from an oligotrophic reservoir in southeastern Brazil. Phytotaxa, 2016, 247(1), 62-74. http://dx.doi. org/10.11646/phytotaxa.247.1.4.

MARRA, R.C., TREMARIN, P.I., ALGARTE, V.M. and LUDWIG, T.V. Epiphytic diatoms (Diatomeae) from Piraquara II urban reservoir, Paraná state. Biota Neotropica, 2016, 16(4), e20160200. http://dx.doi. org/10.1590/1676-0611-BN-2016-0200.

MEDLIN, L.K. and KACZMARSKA, I. Evolution of the diatoms: V. Morphological and cytological support for the major clades and taxonomic revision. Phycologia, 2004, 43(3), 245-270. http://dx.doi. org/10.2216/i0031-8884-43-3-245.1.

METZELTIN, D., LANGE-BERTALOT, H. and GARCÍA-RODRÍGUEZ, F. Diatoms of Uruguay. Compared with other taxa from South America and elsewhere. Iconographia Diatomologica, 2005, 15, $1-736$.

MORALES, E.A. and MANOYLOV, K.M. Morphological studies on selected taxa in the genus Staurosirella Williams et Round (Bacillariophyceae) from rivers in North America. Diatom Research, 2006, 
21(2), 343-364. http://dx.doi.org/10.1080/026924 9X.2006.9705674.

MORALES, E.A. Staurosira incerta (Bacillariophyceae) a new fragilarioid taxon from freshwater systems in the United States with comments on the structure of girdle bands in Staurosira Ehrenberg and Staurosirella Williams et Round. In: N. OGNJANOVARUMENOVA and K. MANOYLOV, eds. Advances in phycological studies. Festschrift in honour of Prof. Dobrina Temniskova-Topalova. Sofia-Moscow: Pensoft Publishers \& University Publishing House, 2006, pp. 133-145.

MORESCO, C., TREMARIN, P.I., LUDWIG, T.A.V. and RODRIGUES, L. Diatomáceas perifíticas abundantes em três córregos com diferentes açóes antrópicas em Maringá, PR, Brasil. Revista Brasileira de Botanica. Brazilian Journal of Botany, 2011, 34(3), 359-373. http://dx.doi.org/10.1590/S010084042011000300010 .

MORO, R.S. and FÜRSTENBERGER, C.B. Catálogo dos principais parâmetros ecológicos de diatomáceas não-marinhas. Ponta Grossa: Editora da Universidade Estadual de Ponta Grossa, 1997.

MOURA, A.N. and BITTENCOURT-OLIVEIRA, M.C. Diatoms (Bacillariophyceae) of the Tibagi River, southern Brazil. Algological Studies, 2004, 112(1), 73-87. http://dx.doi.org/10.1127/18641318/2004/0112-0073.

NARDELLI, M.S., BUENO, N.C., LUDWIG, T.A.V., TREMARIN, P.I. and BARTOZEK, E.C.R. Coscinodiscophyceae and Fragilariophyceae (Diatomeae) in the Iguaçu River, Paraná, Brazil. Acta Botanica Brasílica, 2014, 28(1), 127-140. http:// dx.doi.org/10.1590/S0102-33062014000100013.

NASCIMENTO, M.N. Biodiversidade e distribuição das diatomáceas planctônicas e de sedimento superficial em represa profunda oligotrófica (Sistema Cantareira, Represa Jaguari-Jacareí) [Dissertação de Mestrado]. São Paulo: Instituto de Botânica da Secretaria de Estado do Meio Ambiente, 2012.

OKSANEN, J., BLANCHET, G.F., KINDT, R., LEGENDRE, P., O'HARA, R.B., GAVIN, L., SIMPSON, P.S., HENRY, M., STEVENS, H. and WAGNER, H. Vegan: community ecology package. $R$ package version 2.3-5 [online]. Vienna: The $\mathrm{R}$ Foundation, 2016 [viewed 8 May 2013]. Available from: https:/CRAN.R-project.org/package=vegan

OLIVEIRA, M.A., TORGAN, L.C. and RODRIGUES, S.C. Diatomáceas perifíticas dos arroios Sampaio e Sampainho, Rio Grande do Sul, Brasil. Acta Botanica Brasílica, 2002, 16(2), 151-160. http://dx.doi. org/10.1590/S0102-33062002000200003.

PAPPAS, J. and STOERMER, E.F. Quantitative method for determining a representative algal sample count. Journal of Phycology, 1996, 32(4), 693-696. http:// dx.doi.org/10.1111/j.0022-3646.1996.00693.x.
R CORE TEAM. R: A language and environment for statistical computing [software]. Vienna: The R Foundation, 2014.

RAUPP, S.V., TORGAN, L.C. and BAPTISTA, L.R.M. Composição e variação temporal de diatomáceas (Bacillariophyta) no plâncton da represa de Canastra, sul do Brasil. Iheringia. Série Botânica, 2006, 61(12), 105-134.

REICHARDT, E. Gomphonema gracile Ehrenberg sensu stricto et sensu auct. (Bacillariophyceae): A taxonomic revision. Nova Hedwigia, 2015, 101(3-4), 367-393. http://dx.doi.org/10.1127/ nova_hedwigia/2015/0275.

RESENDE, P., AZEITEIRO, U. and PEREIRA, M.J. Diatom ecological preferences in a shallow temperate estuary (Ria de Aveiro, Western Portugal). Hydrobiologia, 2005, 544(1), 77-88. http://dx.doi. org/10.1007/s10750-004-8335-9.

REYNOLDS, C.S., HUSZAR, V., KRUK, C., NASELLI-FLORES, L. and MELO, S. Towards a functional classification of the freshwater phytoplankton. Journal of Plankton Research, 2002, 24(5), 417-428. http://dx.doi.org/10.1093/ plankt/24.5.417.

ROCHA, A.C.R. and BICUDO, C.E.M. Criptógamos do Parque Estadual das Fontes do Ipiranga, São Paulo, SP. Algas, 25: Bacillariophyceae (Naviculales: Pinnulariaceae). Hoehnea, 2008 , 35(4), 597-618. http://dx.doi.org/10.1590/S223689062008000400011.

ROCHA, A.C.R. Influência do hábitat e estado trófico na biodiverisdade e distribuição das diatomáceas (Bacillariophyta) em reservatórios da sub-bacia do Alto Rio Tietê, Sáo Paulo [Tese de Doutorado]. Rio Claro: Universidade Estadual Paulista, Instituto de Biociências de Rio Claro, 2012.

ROUND, F.E., CRAWFORD, R.M. and MANN, D.G. The diatoms. Biology \& morphology of the genera. New York: Cambridge University Press, 1990.

SÃO PAULO. Parque Estadual do Jurupará. Resumo Executivo. Plano de Manejo. São Paulo: Fundação Florestal do Estado de São Paulo, Secretaria do Meio Ambiente, Governo do Estado de São Paulo, 2010.

SAROS, J.E. and ANDERSON, N.J. The ecology of the planktonic diatom Cyclotella and its implications for global environmental change studies. Biological Reviews of the Cambridge Philosophical Society, 2015, 90(2), 522-541. http://dx.doi.org/10.1111/ brv.12120. PMid:24917134.

SARTORY, D.P. and GROBBELAAR, J.U. Extraction of chlorophyll $a$ from freshwater phytoplankton for spectrophotometric analysis. Hydrobiologia, 1984, 114(3), 177-187. http://dx.doi.org/10.1007/ BF00031869.

SILVA, A.M., LUDWIG, T.A.V., TREMARIN, P.I. and VERCELLINO, I.S. Diatomáceas perifíticas 
em um sistema eutrófico brasileiro (Reservatório do Iraí, estado do Paraná). Acta Botanica Brasílica, 2010, 24(4), 997-1016. http://dx.doi.org/10.1590/ S0102-33062010000400015.

SILVA, W.J., RUWER, D., NOGUEIRA, I. and DUNCK, B. The genus Pinnularia (Bacillariophyta, Pinnulariaceae) from Lago dos Tigres, Britânia, Goiás, Brazil. Biota Neotropica, 2016, 16(1), e20150028. http://dx.doi.org/10.1590/1676-0611BN-2015-0028.

SIVER, P.A. and KLING, H. Morphological observations of Aulacoseira using scanning electron microscopy. Canadian Journal of Botany, 1997, 75(11), 1807. 1835. http://dx.doi.org/10.1139/b97-894.

SOININEN, J., LENNON, J.J. and HILLEBRAND, H. A multivariate analysis of beta diversity across organisms and environments. Ecology, 2007, 88(11), 2830-2838. http://dx.doi.org/10.1890/06-1730.1. PMid:18051652.

SOUZA-MOSIMANN, R.M., LAUDARES-SILVA, R., TALGATTI, D.M. and D'AQUINO-ROSA, V. The diatom flora in Conceição Lagoon, Florianópolis, SC, Brazil. Insula, 2011, 40, 25-54.

STENGER-KOVÁCS, C., BUCZKÓ, K., HAJNAL, É. and PADISÁK, J. Epiphytic, littoral diatoms as bioindicators of shallow lake trophic status: Trophic Diatom Index for Lakes (TDIL) developed in Hungary. Hydrobiologia, 2007, 589(1), 141-154. http://dx.doi.org/10.1007/s10750-007-0729-z.

STOERMER, E.F. Diatoms from the Great Lakes. I. Rare or poorly known species of the genera Diploneis, Oestrupia, and Stauroneis. Journal of Great Lakes Research, 1978, 4(2), 170-177. http://dx.doi. org/10.1016/S0380-1330(78)72181-7.

TAYLOR, J.C., PRYGIEL, J., VOSLOO, A., REY, P.A. and VAN RENSBURG, L. Can diatom-based pollution indices be used for biomonitoring in South Africa? A case study of the Crocodile West and Marico water management area. Hydrobiologia, 2007, 592(1), 455-464. http://dx.doi.org/10.1007/ s10750-007-0788-1.

TUJI, A., LEELAHAKRIENGKRAI, P. and PEERAPORNPISAL, Y. Distribution and phylogeny of Spicaticribra kingstonii-rudis species complex. Memoirs of the National Science Museum National Science, 2012, 48, 139-148.

TUNDISI, J.G. Novas perspectivas para a gestão de recursos hídricos. Revista USP, 2006, 70, 24 35. http://dx.doi.org/10.11606/issn.2316-9036. v0i70p24-35.
VAN DAM, H., MERTENS, A. and SINKELDAM, $\mathrm{J}$. A coded checklist and ecological indicator values of freshwater diatoms from The Netherlands. Netherlands Journal of Aquatic Ecology, 1994, 28(1), 117-133. http://dx.doi.org/10.1007/BF02334251.

VERCELLINO, I.S. and BICUDO, D.C. Sucessão da comunidade de algas perifíticas em reservatório oligotrófico tropical (São Paulo, Brasil): comparação entre período seco e chuvoso. Revista Brasileira de Botanica. Brazilian Journal of Botany, 2006, 29(3), 363-377. http://dx.doi.org/10.1590/S010084042006000300004 .

VESELÁ, J., URBÁNKOVÁ, P., ČERNÁ, K. and NEUSTUPA, J. Ecological variation within traditional diatom morphospecies: diversity of Frustulia rhomboides sensu lato (Bacillariophyceae) in European freshwater habitats. Phycologia, 2012, 51(5), 552-561. http://dx.doi.org/10.2216/11101.1 .

WENGRAT, S. and BICUDO, D.C. Spatial evaluation of water quality in an urban reservoir (Billings Complex, southeastern Brazil). Acta Limnologica Brasiliensia, 2011, 23(2), 200-216. http://dx.doi. org/10.1590/S2179-975X2011000200010.

WENGRAT, S., MARQUARDT, G.C., BICUDO, D.C., BICUDO, C.E.M., WETZEL, C.E. and ECTOR, L. Type analysis of Cymbella schubartii and two new Encyonopsis species (Bacillariophyceae) from southeastern Brazil. Phytotaxa, 2015, 221(3), 247264. http://dx.doi.org/10.11646/phytotaxa.221.3.3.

WENGRAT, S., MORALES, E.A., WETZEL, C.E., ALMEIDA, P.D., ECTOR, L. and BICUDO, D.C. Taxonomy and ecology of Fragilaria billingsii sp. nov. and analysis of type material of Synedra rumpens var. fusa (Fragilariaceae, Bacillariophyta) from Brazil. Phytotaxa, 2016, 270(3), 191-202. http://dx.doi. org/10.11646/phytotaxa.270.3.3.

WETZEL, C.E., ECTOR, L., HOFFMANN, L. and BICUDO, D.C. Colonial planktonic Eunotia (Bacillariophyceae) from Brazilian Amazon: Taxonomy and biogeographical considerations on the E. asterionelloides species complex. Nova Hedwigia, 2010, 91(1-2), 49-86. http://dx.doi. org/10.1127/0029-5035/2010/0091-0049.

Received: 07 June 2017 Accepted: 22 February 2018 